OPEN ACCESS

Edited by:

Oliver Jagoutz,

Massachusetts Institute of Technology, United States

Reviewed by:

Marc-Antoine Longpré, Queens College (CUNY)

United States

J. Gregory Shellnutt, National Taiwan Normal University,

Taiwan

*Correspondence:

Scott A. Whattam

sawhatta@gmail.com

Specialty section:

This article was submitted to

Petrology,

a section of the journal

Frontiers in Earth Science

Received: 30 March 2018

Accepted: 26 July 2018

Published: 03 September 2018

Citation:

Whattam SA (2018) Primitive Magmas in the Early Central American Volcanic Arc System Generated by Plume-Induced Subduction Initiation. Front. Earth Sci. 6:114. doi: 10.3389/feart.2018.00114

\section{Primitive Magmas in the Early Central American Volcanic Arc System Generated by Plume-Induced Subduction Initiation}

\author{
Scott A. Whattam* \\ Department of Geosciences, King Fahd University of Petroleum and Minerals, Dhahran, Saudi Arabia
}

Primitive magmatic rocks with $\mathrm{Mg} \# \geq 60$ have been identified in the literature from the Sona-Azuero, Golfito and Chagres-Bayano forearc segments of southern Costa Rica and Panama of the early (75-39 Ma) Central American Volcanic Arc system (CAVAS). Primitive CAVAS basalts are remarkably similar in terms of major and many trace elements to primitive MORB and primitive basalts of the Mariana Arc and share affinities with global intra-oceanic arc tholeiitic and calc-alkaline basalts. Significant differences however, are apparent between primitive lavas of Chagres-Bayano relative to those of Sona-Azuero and Golfito. Primitive Chagres-Bayano lavas record much higher degrees of partial melting and higher amounts of shallow and deep subduction additions (e.g., higher $\mathrm{Ba} / \mathrm{Th}, \mathrm{Th} / \mathrm{Nb}$ ) than those of the older Sona-Azuero and Golfito arc segments which reflects the early petrologic and tectonic evolution of the CAVAS which is similar to other forearc systems. As shown in previous studies, early CAVAS lavas are exceptionally similar in radiogenic isotopic composition to those of the Caribbean Large Igneous Province (CLIP) oceanic plateau at $90 \mathrm{Ma}$, the approximate timing of onset of the volumetrically dominant phase of CLIP magmatism. Moreover, calculated potential temperatures of $1,633 \pm 47^{\circ} \mathrm{C}$ for two Sona-Azuero primitive basalts suggests an anomalously hot mantle source at subduction initiation (SI). These insights are consistent with SI models which require a plume-induced SI scenario and an elevated sub-arc thermal anomaly upon inception of the CAVAS. It is postulated that, in addition to providing an anomalously high temperature regime in the sub-arc mantle at inception of the CAVAS, extrusion of the CLIP also resulted in lithospheric weakening and extension which allowed for production and rapid ascent of a high percentage of primitive magmas.

Keywords: primitive magmas, volcanic arc, mantle plume, subduction, Central America

\section{INTRODUCTION}

Subduction zone magmatism (see review of Pearce and Peate, 1995) results primarily due to slab dehydration and the subsequent transfer of fluids from the dehydrating and metasomatically altered oceanic slab and its sediment cover to the mantle wedge where partial melting occurs (Tatsumi et al., 1983; White and Patchett, 1984; McCulloch and Gamble, 1991; Hawkesworth et al., 1993a,b; Plank and Langmuir, 1993; Ishikawa and Tera, 1999). Magmatic intra-oceanic arc systems (see review of Stern, 2010 and references therein) such as that of which the Central American Volcanic Arc system 
(CAVAS) was at subduction initiation (SI) represent the surface manifestation of large-scale, upper mantle melt extraction events at intra-oceanic subduction zones. The diagnostic chemical signature of subduction zone magmas is enrichment of large ion lithophile elements (LILE) relative to the light rare earth elements (LREE) and high field strength elements (HFSE) (e.g., Arculus, 1994). This signature is a function of a variety of parameters, for example, the mode and extent of partial melting, composition and thermal state of the mantle, and the relative contributions of fluids and sediments to the source. Intra-oceanic arcs represent the most important site of juvenile (mantlederived) continental crust formation and are considered as fundamental building blocks of continents. Estimates of the mass proportion of continents formed at subduction zones are of the order of 85-95\% (Rudnick, 1995; Barth et al., 2000).

Most arc magmas are fractionated and relatively evolved with 4-6 wt. \% MgO (e.g., Tamura and Tatsumi, 2002; Kelemen et al., 2003; Tamura, 2003) and Mg\#'s $(\mathrm{Mg} / \mathrm{Mg}+\mathrm{Fe})$ that are too low to have equilibrated with mantle peridotite. In contrast, high$\mathrm{MgO}(\mathrm{MgO}>8$ wt. $\%$ ) or primary (with $\mathrm{Mg} \#$ of $\sim \geq 70$ and high $\mathrm{Ni}>200 \mathrm{ppm}$ and $\mathrm{Cr}>400 \mathrm{ppm}$ ) magmas (Tatsumi and Eggins, 1995) representing mantle partial melts minimally affected by fractionation, assimilation, mixing and storage are relatively uncommon in modern subduction zone settings. Nonetheless, primary or near-primary lavas ("primitive" lavas least affected by fractional crystallization and assimilation) have been recovered from many intra-oceanic arc systems including the Izu-Bonin Marianas (Tamura et al., 2011, 2013), Solomon Islands (Schuth et al., 2004), Vanuatu (Eggins, 1993), Papua-New Guinea (Smith et al., 1997; Smith, 2013), the Aleutians (Kelemen et al., 2003), Lesser Antilles (Macdonald et al., 2000; Melekhova et al., 2015) the South Sandwich Islands (Leat et al., 2003) and Kamchatka (Hochstaedter et al., 1996; Portnyagin et al., 2007) but are usually volumetrically minor. Primary magmas have unfractionated compositions in equilibrium with upper mantle peridotite (Sato, 1977) and are of great petrological significance and constitute valuable sources of information on the conditions of partial melting and the thermal structure of the mantle wedge beneath volcanic arcs. Information on the conditions of petrogenesis of high-MgO arc basalts has come mainly from experimental studies. Many high-pressure experimental studies on high-MgO arc basalts have been performed under anhydrous (Tatsumi, 1982; Tatsumi et al., 1983, 1994; Gust and Perfit, 1987; Kushiro, 1987; Bartels et al., 1991; Draper and Johnson, 1992; Baker et al., 1994) and hydrous (Tatsumi, 1982; Tatsumi et al., 1983; Baker et al., 1994) conditions. Unfortunately, characteristic experimental $f \mathrm{O}_{2}$ conditions have generally been too reducing for arc settings (Tatsumi, 1982; Tatsumi et al., 1983; Gust and Perfit, 1987; Bartels et al., 1991; Draper and Johnson, 1992) rendering only a very limited number of experimental studies to be applicable to real conditions of basaltic melt generation in subduction zones. A recent study (Schmidt and Jagoutz, 2017) has provided valuable insights into the petrogenesis of global primitive arc melts (see Discussion).

The rarity of primary magmas in arc sequences has been attributed by Smith et al. (1997) to their high density and the relatively buoyant nature of the arc crust, which acts as a barrier to the ascent of dense, Mg-rich magmas and by Leat et al. (2002) to the difficulty in traversing the crust without encountering magma chambers. In a study of phase relationships of magnesian arc magmas, Pichavant and Macdonald (2003) argue that only the most water-poor primitive magmas are able to traverse the crust without adiabatically freezing, explaining the rarity of primitive magmas in arcs. This raises further questions about the extent to which erupted and sampled primary magmas in arcs are typical of mantle-derived melts in arcs. There is a related debate about the origin of high-Al basalts, which have greater than c. 17 wt. $\% \mathrm{Al}_{2} \mathrm{O}_{3}$ and are characteristic of arcs. Crawford et al. (1987) reviewed the arguments and concluded that accumulation of plagioclase was the origin of the high $\mathrm{Al}$ abundances. These debates highlight the difficulty in modeling fractionation histories of arc magmas, even in intra-oceanic arcs, where primitive magmas are usually absent, and both addition and fractional removal of phenocrysts has occurred.

If mantle-derived magmas are Mg-rich, the transition from primitive melts to low-Mg basalts by fractional crystallization must generate significant thicknesses of mafic and ultramafic cumulates. This is consistent with the presence of high-velocity (P-wave velocity $=6.9-7.5 \mathrm{~km} \mathrm{~s}^{-1}$ ) layers several kilometers thick that have been seismically detected at the base of the crust in some intra-oceanic arcs (Suyehiro et al., 1996; Holbrook et al., 1999). Similarly, seismic velocity measurements on samples of exposed lower crust of the exhumed Kohistan Arc (Pakistan) for example, strongly suggest that these high-velocity keels consist of ultramafic cumulates (Miller and Christensen, 1994).

A number of studies have considered the older or early (Late Cretaceous to Eocene) segments of the CAVAS (e.g., Lissinna, 2005; Buchs et al., 2010; Wegner et al., 2011; Montes et al., 2012; Whattam and Stern, 2015). However, none of these studies have considered explicitly the existence of "primitive" lavas in the early (75-39 Ma) CAVAS in southernmost Costa Rica and Panama. I use the terms "primitive" and "evolved" lavas to encompass those

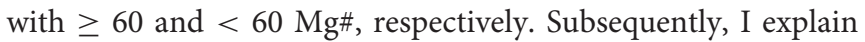
the basic petrogenesis of these high-Mg primitive lavas, compare these with other primitive arc suites and discuss its significance in the context of the chemical and tectonic evolution of the CAVAS.

\section{GEOLOGICAL BACKGROUND AND REGIONAL SETTING}

Presently, the Quaternary to modern-day CAVAS volcanic front stretches $\sim 1,100 \mathrm{~km}$ along the western margin of the Caribbean plate from Costa Rica through Nicaragua, El Salvador and Guatemala to the Guatemala-Mexico border at the southern margin of the North American plate (Figure 1A). However, upon inception of unequivocal arc-related magmatism at the CAVAS by $\sim 75 \mathrm{Ma}$ (Buchs et al., 2010), the volcanic arc system bordered the entirety of southernmost present-day Panama (Lissinna, 2005; Wörner et al., 2009; Buchs et al., 2010; Wegner et al., 2011) and appears to have swept as far east as present-day western Colombia (Lissinna, 2005; Montes et al., 2012; Whattam and Stern, 2015) and possibly as far west as the Nicoya peninsula in present-day northwestern Costa Rica (Whattam and Stern, 


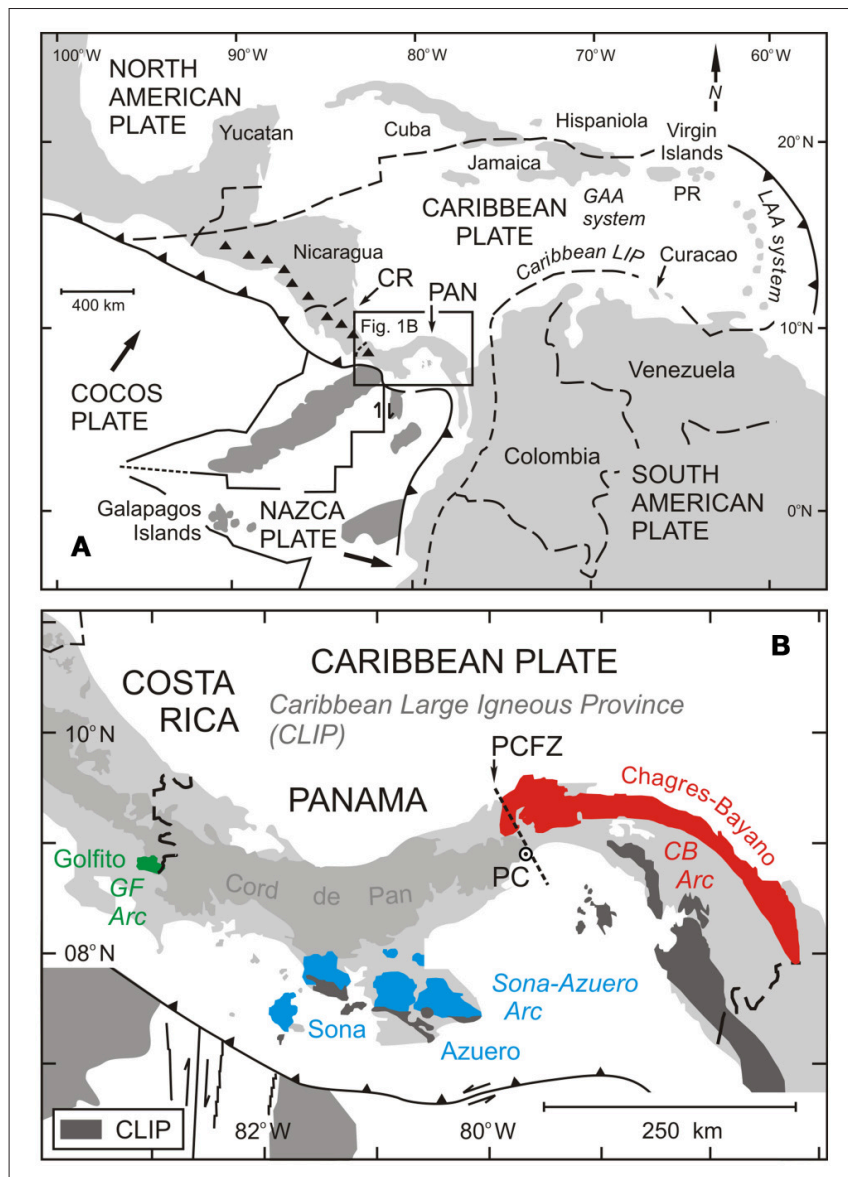

FIGURE 1 | Maps of (A) the greater Caribbean region showing the distribution of the Caribbean Plate and the modern (2.6-0 Ma) Central American Volcanic Arc system (CAVAS, black triangles) and (B) the location and distribution of the three early (75-39 Ma) CAVAS segments at Sona-Azuero, Golfito and Chagres-Bayano investigated in this study.

2015). Inception of subduction at the CAVAS has been posited as the result of plume-induced (Whattam and Stern, 2015) or collision-induced (e.g., Buchs et al., 2010) SI following extrusion of the Caribbean Large Igneous Province (CLIP). Subsequent to northeasterly migration of the CLIP and "sandwiching" of the CLIP between the North and South American continents, the CAVAS was constructed upon the CLIP (e.g., as in Buchs et al., 2010; see also model of Hoernle et al., 2002, which is based on models referenced therein).

After the Eocene, the foci of CAVAS magmatic activity shifted from east to west. Older exposures generated to the east comprise the 75-39 Ma Sona-Azuero, 75-66 Ma Golfito and 70-39 Ma Chagres-Bayano complexes in southernmost Costa Rica and Panama (Figure 1B). The Sona-Azuero and Chagres-Bayano complexes are interpreted as being floored by segments of the 89-85 Ma CLIP (Wörner et al., 2009; Buchs et al., 2010; Wegner et al., 2011; Montes et al., 2012). The Golfito Complex has been interpreted as both CLIP oceanic plateau (Hauff et al., 2000a) and more recently as arc (Buchs et al., 2010). Prior to the study of Buchs et al. (2010), it has generally been assumed that most oceanic forearc units along western Costa Rica and Panama represented uplifted segments of the CLIP (e.g., Hauff et al., 2000a). Similar interpretations have been made for many oceanic complexes along NW South America and the Leeward Antilles (see Whattam and Stern, 2015).

Relatedly, most researchers have posited two separate tectonic environments of formation to explain the oceanic plateauarc association-an initial one for the CLIP at a within-plate setting - and a subsequent, younger one for the arc segments above a subduction zone to the rear of the CLIP. According to this model, CAVAS construction in Panama and southernmost Costa Rica began at $\sim 75 \mathrm{Ma}$ (e.g., Buchs et al., 2010) atop the preexisting CLIP oceanic plateau subsequent to Farallon Plate (now the Cocos Plate) subduction beneath the CLIP plateau (e.g., Hauff et al., 2000a and references therein). Alternatively, Whattam and Stern (2015) consider both units as "plume- and arc-related" ones that represent hybrid units which formed simultaneously to or soon after plateau extrusion in a single, rapidly evolving tectonic environment.

Many CAVAS studies have focused on the geochemical and isotopic evolution of the Quaternary to modern-day volcanic front (e.g., see references in CentAm and IBM Geochem Database version 1.02 at: http://www.earthchem.org/grl). Two recent papers (Gazel et al., 2015; Whattam and Stern, 2016) have provided synergistic chemotemporal treatments of the CAVAS from inception at $\sim 75 \mathrm{Ma}$ to the present day in Costa Rica and Nicaragua. In each of these studies (Gazel et al., 2015; Whattam and Stern, 2016) it was concluded that the production of arc magmas with continental crust compositions was achieved in the CAVAS by about $15 \mathrm{Ma}$. It was further demonstrated by Whattam and Stern (2016) that the CAVAS records a gradual enrichment in incompatible element concentrations with time which they attributed to gradual thickening of the arc substrate and depression of mantle geotherms and a concomitant decrease in the degree of partial melting. For a more in-depth treatment of the chemical aspects and evolution of the CAVAS, I refer readers to the aforementioned studies.

\section{SAMPLES AND METHODS}

Primitive lavas (those with $\geq 60 \mathrm{Mg \# )}$ ) in the literature from three early (75-39 Ma) CAVAS forearc segments at Sona-Azuero (Buchs et al., 2010; Wegner et al., 2011; Whattam et al., under review) and Chagres-Bayano (Wegner et al., 2011; Montes et al., 2012) in southwestern and eastern Panama, respectively, and Golfito (Buchs et al., 2010) of southernmost Costa Rica (Figure 1, Table 1) are recognized. The number of primitive lava samples identified from Sona-Azuero, Chagres-Bayano and Golfito is 6, 17 and 3 respectively, which comprise 11,19 , and $38 \%$ of the total (that is, primitive plus non-primitive, or evolved) samples of each complex (Figure 2). For comparison with early CAVAS primitive magmas, I also use compositions of primitive MORB (Jenner and O'Neill, 2012), primitive lavas of segments of two western Pacific arc systems at Papua, New Guinea (Smith et al., 1997; Smith, 2013) and the Izu-Bonin Mariana Arc system (Tamura et al., 2011) and global intra-oceanic arcs (Schmidt and Jagoutz, 2017). 


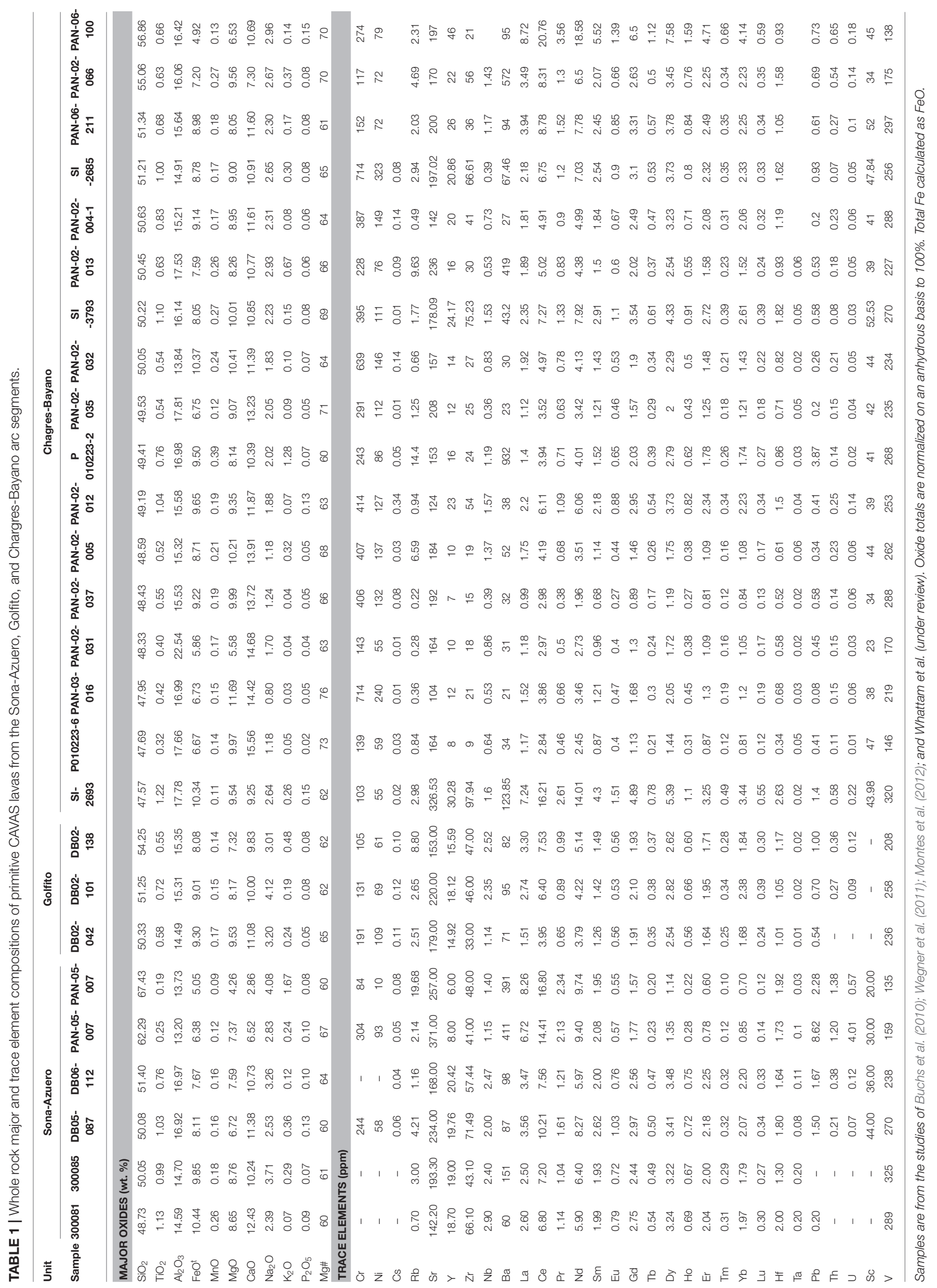




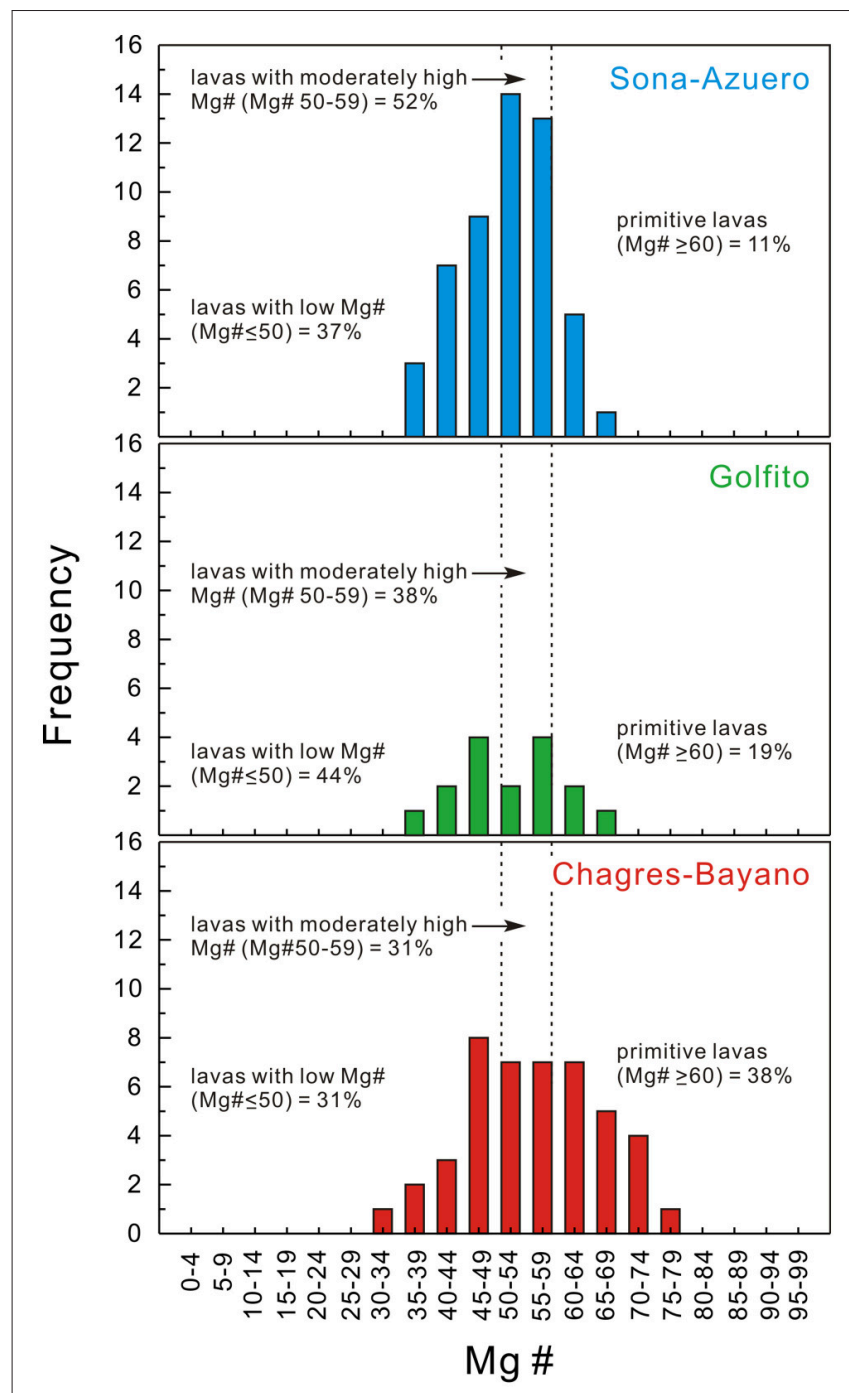

FIGURE 2 | Histograms of Mg\# of Sona-Azuero, Golfito, and Chagres-Bayano lavas to demonstrate the number of lavas of each suite which have low Mg\#, moderately high $\mathrm{Mg \#}$ and high Mg\#.

Samples were filtered to include only volcanic rocks with loss on ignition (LOI) $<3$ wt. \% which yield anhydrous oxide totals of 96-101 wt. \%. In the case of the datasets of Wegner et al. (2011), which do not provide LOI, only the 96-101 wt. \% filter is applied. In the study of Buchs et al. (2010) major elements were analyzed via an X-Ray fluorescence (XRF) spectrometer and trace element concentrations were obtained on a laser ablation inductively coupled plasma mass spectrometer (LA-ICP-MS). In the study of Wegner et al. (2011), concentrations of major and minor elements ( $\mathrm{Si}, \mathrm{Ti}, \mathrm{Al}, \mathrm{Fe}, \mathrm{Mn}, \mathrm{Mg}, \mathrm{Ca}, \mathrm{Na}, \mathrm{K}$, and $\mathrm{P}$ ) as well as selected trace elements (Nb, Zr, Y, Sr, Rb, Ga, Zn, Cu, $\mathrm{Ni}, \mathrm{Co}, \mathrm{Cr}, \mathrm{V}, \mathrm{Ba}$, and Sc) were analyzed by XRF whereas the REE, high-field strength elements (HFSE: Nb, Ta, Zr, and Hf), large-ion lithophile elements (LILE: $\mathrm{Rb}, \mathrm{Sr}, \mathrm{Ba}$, and $\mathrm{Cs}$ ) and a group of other trace elements ( $\mathrm{Li}, \mathrm{Sc}, \mathrm{Cu}, \mathrm{V}, \mathrm{Cr}, \mathrm{Co}, \mathrm{Ni}, \mathrm{Zn}$, $\mathrm{Y}, \mathrm{Pb}, \mathrm{Th}$, and $\mathrm{U}$ ) were analyzed via ICP-MS. In the study of
Montes et al. (2012), major elements were determined by XRF and trace elements via LA-ICP-MS whereas the in the study of Whattam et al. (under review), major and trace elements were determined by ICP-atomic emission spectrometry (ICPAES).

\section{RESULTS}

\section{Etrography, Alteration, and Low-T Metamorphism}

As this is a study of data in the literature, most samples discussed are not available for petrographic description. Nonetheless, according to the literature from which these samples are recognized (Buchs et al., 2010; Wegner et al., 2011; Montes et al., 2012) including Whattam et al. (under review), the Sona-Azuero and Golfito lavas consist essentially of clinopyroxene, plagioclase and groundmass; olivine is not present. For example, in the aforementioned papers there is no mention of olivine apart from it comprising the non-arc related plateau and enriched Type II basalts (Buchs et al., 2010; Whattam et al., under review). According to Whattam et al. (under review), Azuero evolved lavas usually display micro-porphyritic and sometimes robustly porphyritic textures defined by large $(1.5-2.0 \mathrm{~mm})$, commonly euhedral, fresh clinopyroxene phenocrysts. The crystallization sequence is clinopyroxene followed by plagioclase which is typical of hydrous (i.e., arc) magmas in which early plagioclase crystallization is suppressed (Pearce et al., 1984; Cameron, 1985; Sisson and Grove, 1993).

Though the studies of Buchs et al. (2010), Wegner et al. (2011), Montes et al. (2012) and Whattam et al. (under review) concede some alteration, the samples considered were chosen on the basis of freshness and only samples with oxide totals of 96-102 wt. \% and LOI $<3.0$ wt. $\%$ are considered in this study. To demonstrate the apparent freshness of the primitive samples of this study, I plot all primitive and evolved lavas of Sona-Azuero, Golfito and Chagres-Bayano in total alkalis vs. $\mathrm{SiO}_{2}$ (TAS) (Figure 3A) and $\mathrm{Zr} / \mathrm{Ti}$ vs. $\mathrm{Nb} / \mathrm{Y}$ (Figure 3B) space. I use these plots not for classification purposes but rather for comparative ones in order to look at possible alteration. For example, $\mathrm{SiO}_{2}, \mathrm{~K}_{2} \mathrm{O}$, and $\mathrm{Na}_{2} \mathrm{O}$ are known to be mobile whereas $\mathrm{Zr}, \mathrm{Ti}, \mathrm{Nb}$, and $\mathrm{Y}$ are not. Thus, by comparing Figure 3A with Figure 3B I can comment on the apparent alteration undergone by these CAVAS forearc lavas. A comparison of Figures 3A,B demonstrates that a moderate number of evolved samples have elevated total alkalis which results in their plotting within the alkaline lavas fields in Figure 3A, which is likely the result of mobilization of these elements and alteration as these same samples do not plot as alkaline in Figure 3B. I note that none of the primitive samples appear to have been subjected to the addition of alkalis.

Furthermore, a plot of LOI vs. various potentially mobile elements $\left(\mathrm{MgO}, \mathrm{K}_{2} \mathrm{O}, \mathrm{CaO}, \mathrm{Na}_{2} \mathrm{O}\right.$, and $\mathrm{Ba}$, Supplementary Figure 1) show no correlation suggesting that these CAVAS have not been significantly affected by alteration. Finally, my geochemical plots and arguments rely primarily on trace elements known to be immobile up to greenschist-facies metamorphic conditions. 

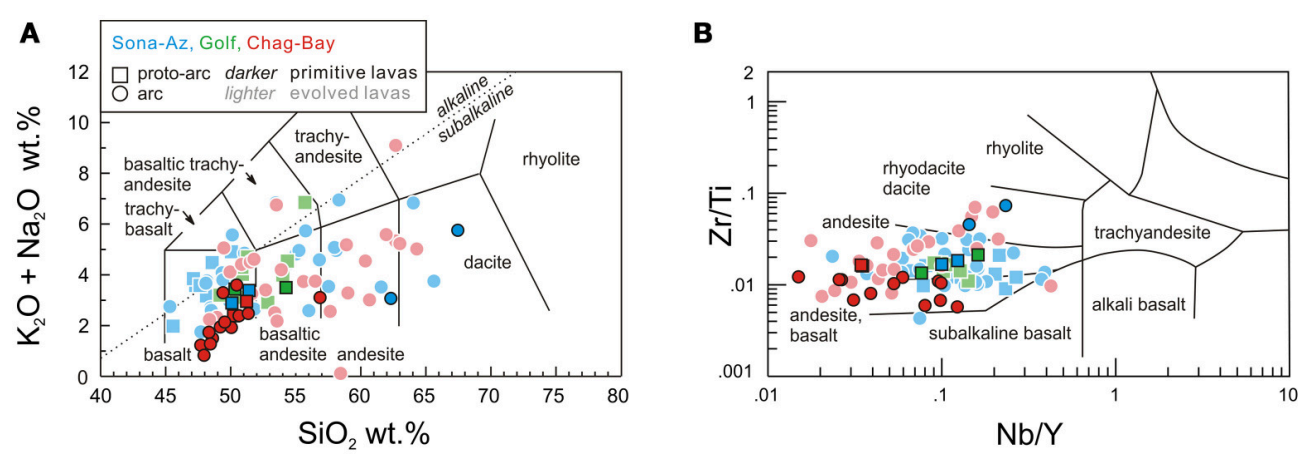

FIGURE 3 | (A) Total alkalis-silica (TAS) (Le Bas et al., 1986) and (B) Zr/Ti vs. Nb/Y (Winchester and Floyd, 1977) plots of primitive and evolved lavas of Sona-Azuero, Golfito and Chagres-Bayano. Note that one evolved Chagres-Bayano basalt plots of the diagram to the left with $\sim 0.006 \mathrm{Nb} / \mathrm{Y}$ and $0.007 \mathrm{Zr} / \mathrm{Ti}$. Abbreviations: PA, A and $\mathrm{A}$ beside symbols here and in subsequent figures: proto-arc, arc (squares, circles).

\section{Olivine Accumulation}

As the lavas considered in this study comprise nil reported olivine, the high $\mathrm{MgO}$ contents (up to 10.41 wt. \% $\mathrm{MgO}$ ) are likely not the result of olivine accumulation. Plots of $\mathrm{FeO}^{\mathrm{t}}$ vs. $\mathrm{MgO}$ (Supplementary Figure 2A) support that no olivine accumulation (i.e., a trend of decreasing $\mathrm{MgO}$ with decreasing $\mathrm{FeO}^{\mathrm{t}}$ ) occurred, whereas high correlation between $\mathrm{Cr}$ and $\mathrm{Ni}$ with $\mathrm{R}^{2}$ values of $0.83-0.96$ (Supplementary Figure $2 \mathrm{~B}$ ) supports this conclusion.

\section{Relation Between Primitivity and Age}

Although ages (Wegner et al., 2011) are available for only some of the samples considered in this study (Table 2) the available ages demonstrate that the three oldest ones have $\mathrm{Mg} \#>60$ and that primitive lava production was restricted to the interval between subduction inception and $\sim 66 \mathrm{Ma}$. This suggests that at least some of the oldest samples which have been generated soon after subduction inception are primitive and that assuming a relation between plume emplacement and generation of early primitive lavas may be valid. Moreover, five primitive samples are protoarc basalts and these basalts are assumed to have formed early in the evolution of the CAVAS circa 75-66 Ma (Buchs et al., 2010).

\section{$\mathrm{MgO}, \mathrm{Ni}$, and $\mathrm{Cr}$ Contents}

Primary magmas are ones in equilibrium with mantle peridotite and hence have high $\mathrm{MgO}$ and compatible element $(\mathrm{Ni}, \mathrm{Cr})$ concentrations. A line of $\mathrm{MgO}=30-\left(0.43 \times \mathrm{SiO}_{2}\right)$ was empirically derived by Smith and Mitchell (1989) to delineate a suite of high-Mg lavas of the Papuan volcanic arc which plot above the line in $\mathrm{SiO}_{2}$ vs. $\mathrm{MgO}$ space from low-Mg lavas which plot below the line. In Figure $4 \mathrm{I}$ plot $\mathrm{MgO}$ vs. $\mathrm{SiO}_{2}$ of all early CAVAS lavas with the line of $\mathrm{MgO}=30-\left(0.43 \times \mathrm{SiO}_{2}\right)$ superimposed upon it. This line demarcates primitive from nonprimitive CAVAS lavas relatively well but with some exceptions. For example, $15 \%$ ( 11 of 74 ) of non-primitive (evolved) lavas with $\mathrm{Mg} \#<60$ plot above the line of $\mathrm{MgO}=30-\left(0.43 \times \mathrm{SiO}_{2}\right)$ whereas 29\% (6 of 21) of primitive lavas with $\mathrm{Mg \#} \geq 60$ plot below this line. Also superimposed on Figure 4 are two dotted lines at $\mathrm{SiO}_{2}=52$ wt. $\%$ and $\mathrm{MgO}=8$ wt. \% to demonstrate
TABLE 2 | Relation between age and primitivity.

\begin{tabular}{llcll}
\hline Complex & Sample & Age (Ma) & Mg\# & Reason not used in plots \\
\hline Sona-Azuero & PAN-05-017 & 71 & 60 & NA \\
Sona-Azuero & PAN-05-008 & 67 & 63 & Total oxides < 96 wt. \% \\
Chagres-Bayano & PAN-06-100 & 66 & 70 & NA \\
Chagres-Bayano & PAN-03-023 & 66 & 53 & NA \\
Chagres-Bayano & PAN-03-022 & 66 & 49 & Plutonic \\
Chagres-Bayano & PAN-03-004 & 61 & 56 & Plutonic \\
Chagres-Bayano & PAN-06-210 & 51 & 47 & NA \\
Chagres-Bayano & PAN-06-206 & 50 & 49 & Plutonic \\
Chagres-Bayano & PAN-03-007 & 49 & 69 & Plutonic \\
Chagres-Bayano & PAN-04-004 & 49 & 48 & NA \\
Chagres-Bayano & PAN-04-011 & 47 & 50 & Plutonic \\
Chagres-Bayano & PAN-03-029 & 47 & 59 & NA \\
Chagres-Bayano & PAN-06-103 & 45 & 45 & NA
\end{tabular}

Samples and ages are from Wegner et al. (2011).

that the majority of primitive basalts $(67 \%)$ have $>8 \mathrm{wt} . \% \mathrm{MgO}$ whereas only $7 \%$ of the evolved basalts have $>8$ wt. $\% \mathrm{MgO}$.

A plot of Cr vs. Ni (Supplementary Figure 2B) demonstrates that the vast majority $(70 \%)$ of the primitive lavas have either $>100 \mathrm{ppm} \mathrm{Ni}$ or $>150 \mathrm{ppm} \mathrm{Cr}$ or both. The Chagres-Bayano primitive lavas are the most $\mathrm{Ni}$ and $\mathrm{Cr}$ rich and reach $\mathrm{Ni}$ and $\mathrm{Cr}$ contents of $323 \mathrm{ppm}$ and $714 \mathrm{ppm}$, respectively. In contrast, most evolved lavas have $<50 \mathrm{ppm} \mathrm{Ni}$ and $<100 \mathrm{ppm}$ Cr. The CAVAS primitive lavas are similar in terms of $\mathrm{Ni}$ and $\mathrm{Cr}$ contents with primitive MORB and primitive lavas of the Mariana and Papuan arcs but three Chagres-Bayano primitive samples extend to both higher $\mathrm{Ni}$ and $\mathrm{Cr}$ concentrations than all three of these suites.

\section{Chondrite Normalized REE and N-MORB Normalized Patterns}

Chondrite normalized REE patterns of early CAVAS basalts are shown in Figure 5. Primitive lavas of the Sona-Azuero and Golfito suites comprise a relatively low percentage of the total samples (9 and 18\% respectively, Figure 2 ) and in each 


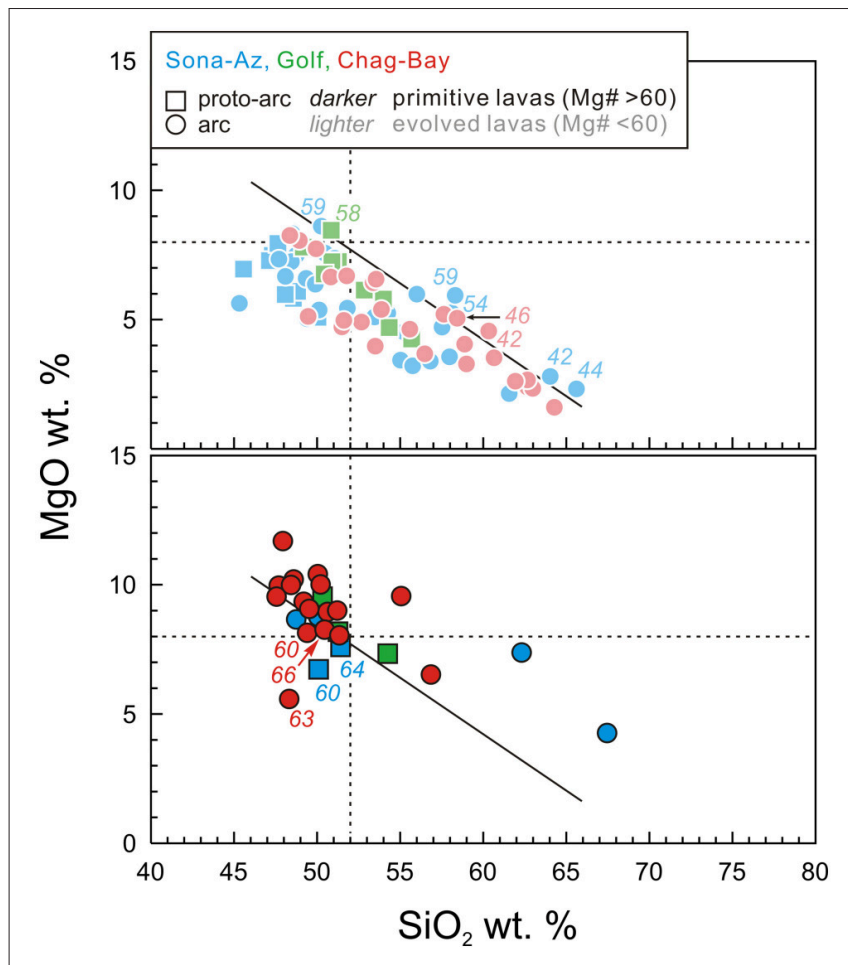

FIGURE 4 | $\mathrm{SiO}_{2}$ vs. MgO of evolved lavas ( $\mathrm{Mg \#}<60$, top) and primitive lavas (Mg\# $>60$, bottom) of Sona-Azuero, Golfito and Chagres-Bayano. The black line in each plot represents the equation $\mathrm{MgO}=30-\left(0.43^{*} \mathrm{SiO}_{2}\right)(\mathrm{Smith}$ and Mitchell, 1989) (see text) which subdivides primitive Papuan Arc lavas which plot above the line from normal or evolved Papuan Arc lavas. The numbers in italics represent $\mathrm{Mg} \#$ of the adjacent symbols.

suite, the $\sum$ REE of the primitive basalts are lower than that of the evolved basalts. In the case of the Sona-Azuero suite, the $\sum \mathrm{REE}$ of the primitive basalts range from 54 to 60 and exhibit REE concentrations of $\sim 15 \times$ chondrite whereas the evolved basalts exhibit a $\sum$ REE range of 31-208. Chondrite normalized $\mathrm{La} / \mathrm{Yb}\left([\mathrm{La} / \mathrm{Yb}]_{\mathrm{CN}}\right)$ also rises to much higher values in the evolved Sona-Azuero basalts relative to the primitive Sona-Azuero basalts. REE patterns of the primitive Sona-Azuero basalts are flat to slightly LREE-enriched $\left([\mathrm{La} / \mathrm{Yb}]_{\mathrm{CN}}=1.13-\right.$ 1.24) whereas the REE patterns of the evolved basalts range to moderately fractionated patterns $\left([\mathrm{La} / \mathrm{Yb}]_{\mathrm{CN}}=0.75-3.45\right)$. Similarly, the primitive Golfito basalts exhibit lower $\sum$ REE (21-27) than their evolved counterparts ( $\sum \mathrm{REE}$ of $49-59$ ). $[\mathrm{La} / \mathrm{Yb}]_{\mathrm{CN}}$ of the primitive Golfito basalts are $0.64-0.83$ whereas the evolved Golfito basalts exhibit $[\mathrm{La} / \mathrm{Yb}]_{\mathrm{CN}}$ of $0.61-0.88$. In contrast, primitive lavas occupy a high percentage of the Chagres-Bayano suite (37\%) and the primitive basalts overlap the evolved basalts in terms of both $\sum$ REE and $[\mathrm{La} / \mathrm{Yb}]_{\mathrm{CN}}$. Primitive Chagres-Bayano basalts have $\sum$ REE of 19-96 and $[\mathrm{La} / \mathrm{Yb}]_{\mathrm{CN}}$ of $0.58-1.51$ whereas the evolved Chagres-Bayano basalts have $\sum \mathrm{REE}$ of $39-87$ and $[\mathrm{La} / \mathrm{Yb}]_{\mathrm{CN}}$ of $0.43-3.28$. That the primitive Chagres-Bayano basalts range to the lowest $\sum \mathrm{REE}$ and $[\mathrm{La} / \mathrm{Yb}]_{\mathrm{CN}}$ suggests that they were derived from a more depleted source and/or higher degrees of partial

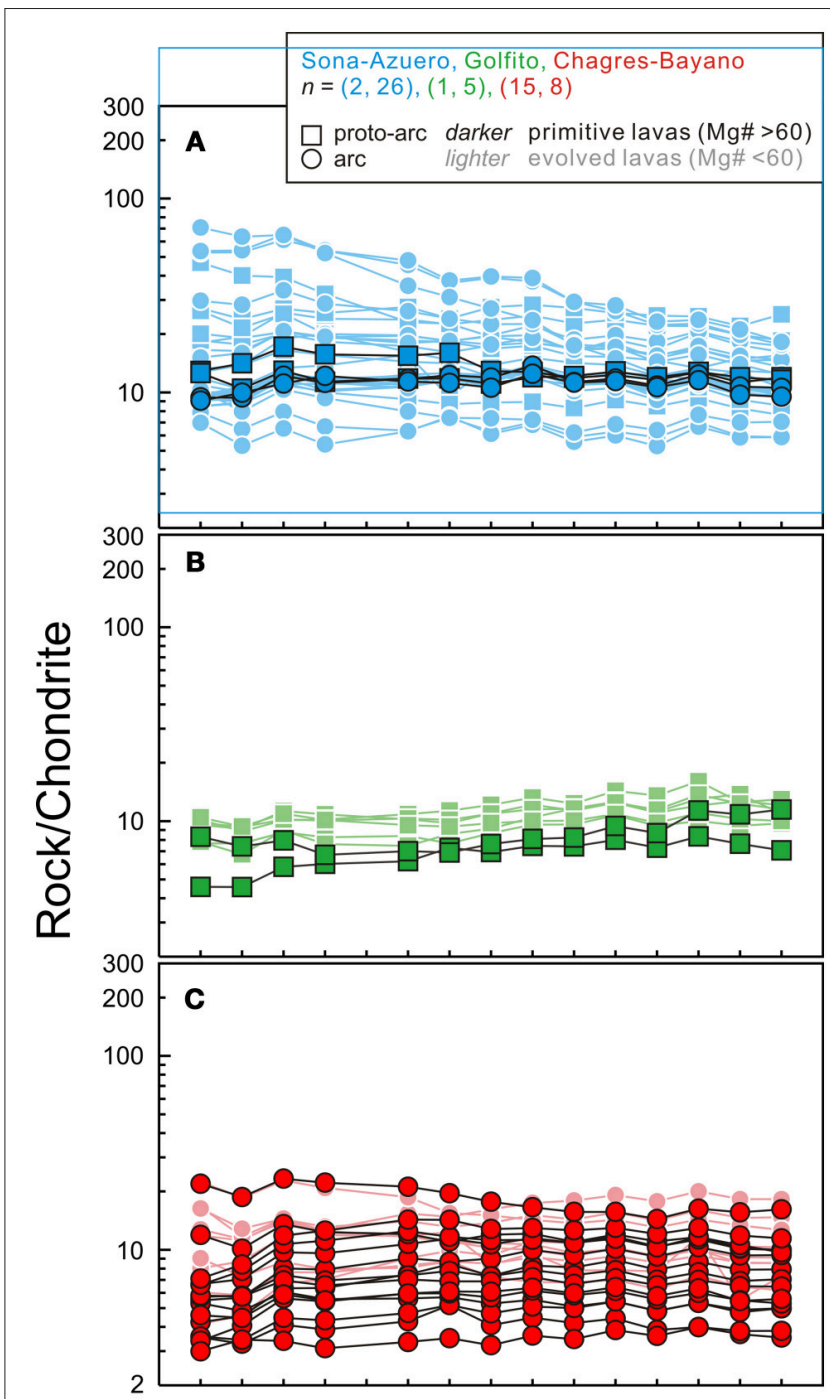

La Ce Pr NdPm Sm Eu Gd Tb Dy Ho Er Tm Yb Lu

FIGURE 5 | Chondrite normalized REE concentrations of primitive basalts of (A) Sona-Azuero, (B) Golfito, and (C) Chagres-Bayano vs. evolved basalts of each arc segment. Chondrite abundances from Sun and McDonough (1989).

melting than the Sona-Azuero and Golfito lavas. In all three suites, the HREE from Ho to Lu have gentle slopes or are nearly flat which demonstrates the general absence of residual garnet in the source of all three suites, a feature of which is characteristic of global arc suites (Schmidt and Jagoutz, 2017).

N-MORB normalized patterns of the primitive early CAVAS lavas are shown in Figure 6. All three arc segments exhibit the classical features of arc magmatism, that is, LILE enrichment and HFSE depletion. Superimposed on the background of Figure 6 are the N-MORB normalized patterns of the evolved lavas of each suite which highlights differences between the primitive and evolved lavas although the patterns are broadly similar. In terms of LILE enrichment among the primitive suites, the Sona-Azuero and Golfito arc segments are mildly enriched (e.g., 


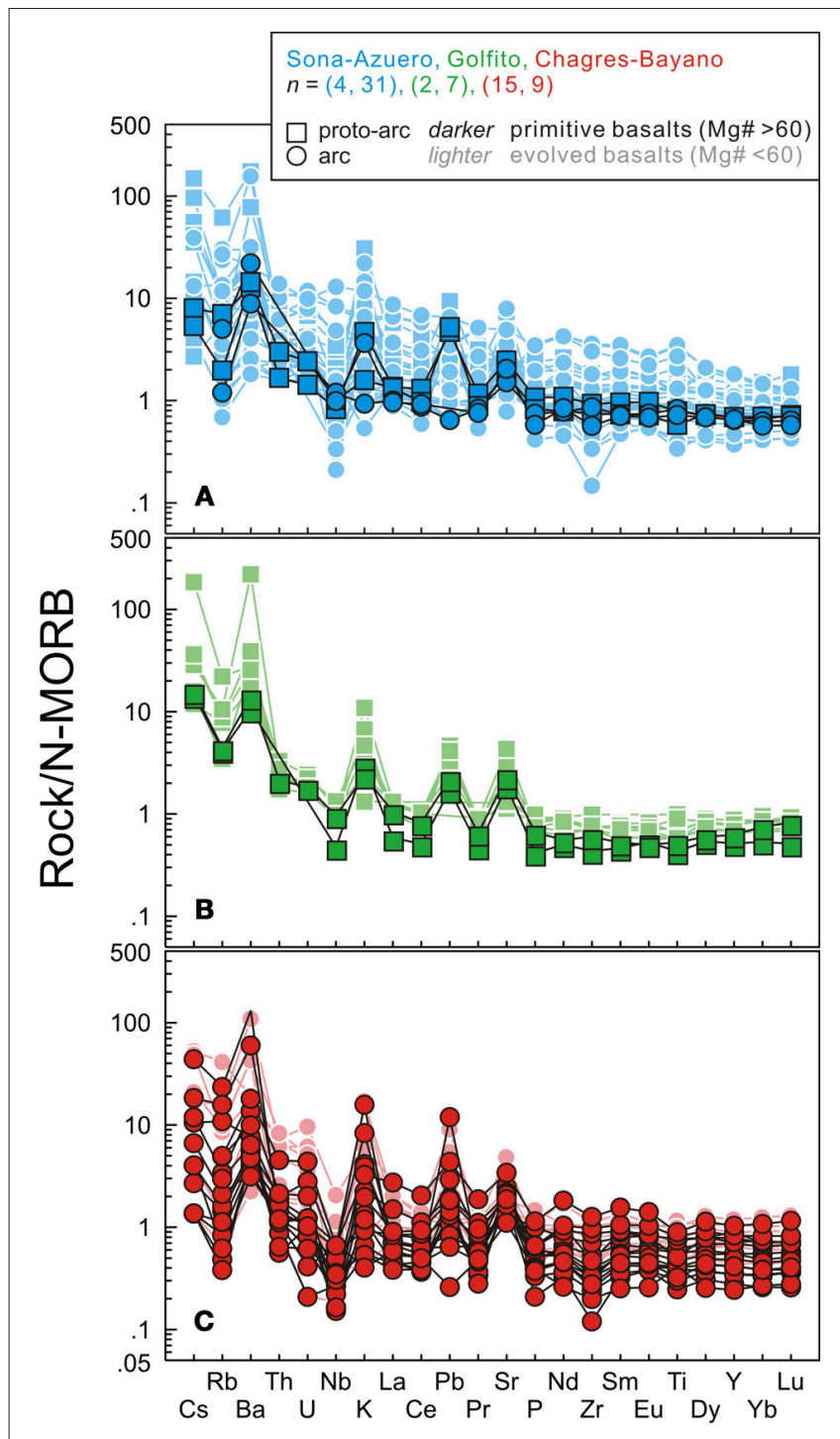

FIGURE 6 | N-MORB normalized concentrations of primitive basalts of (A) Sona-Azuero, (B) Golfito, and (C) Chagres-Bayano vs. evolved basalts of each arc segment. N-MORB abundances from Sun and McDonough (1989).

N-MORB normalized $\mathrm{Ba}\left([\mathrm{Ba}]_{\mathrm{NMM}}\right)$ of $\left.11-16\right)$ whereas the Chagres-Bayano arc segment ranges to strongly LILE enriched ([Ba $\left.]_{\mathrm{NMM}}\right]$ of up to 148$)$.

\section{DISCUSSION}

\section{Silica Variation Diagrams}

On Figure 7, I plot $\mathrm{SiO}_{2}$ vs. major element oxides (Figure 7A), selected trace elements (Figure 7B) and trace element ratios (Figure 7C) of primitive CAVAS lavas and for comparison, evolved CAVAS lavas. For further comparison, I also plot primitive MORB (Jenner and O’Neill, 2012) and primitive Mariana (Tamura et al., 2011) and Papuan (Smith et al., 1997; Smith, 2013) arc lavas. In the CAVAS primitive suite, $\mathrm{TiO}_{2}$,
$\mathrm{FeO}^{\mathrm{t}}, \mathrm{MgO}$, and $\mathrm{CaO}$ decrease with increasing $\mathrm{SiO}_{2}$ whereas $\mathrm{K}_{2} \mathrm{O}$ and $\mathrm{Na}_{2} \mathrm{O}$ increase; $\mathrm{Al}_{2} \mathrm{O}_{3}$ and $\mathrm{P}_{2} \mathrm{O}_{5}$ show little change (Figure 7A). Compared with their evolved counterpart lavas, the primitive CAVAS lavas range to lower $\mathrm{TiO}_{2}, \mathrm{FeO}^{\mathrm{t}}, \mathrm{Na}_{2} \mathrm{O}$, and $\mathrm{P}_{2} \mathrm{O}_{5}$ and higher $\mathrm{MgO}$ and $\mathrm{CaO}$. The primitive CAVAS basalts are compositionally very similar to primitive MORB in terms of major element concentrations but range to lower $\mathrm{TiO}_{2}$, $\mathrm{FeO}^{\mathrm{t}}$, and $\mathrm{Na}_{2} \mathrm{O}$ and higher $\mathrm{CaO}$. The primitive CAVAS lavas are also very similar to those of the Mariana Arc, the major element compositions of which fall completely within the field of primitive MORB. Primitive lavas of the Papuan Arc exhibit significantly higher $\mathrm{TiO}_{2}, \mathrm{~K}_{2} \mathrm{O}$, and $\mathrm{P}_{2} \mathrm{O}_{5}$ than the primitive CAVAS lavas.

Plots of $\mathrm{SiO}_{2}$ vs. Sr, $\mathrm{Zr}, \mathrm{Nb}, \mathrm{Hf}, \mathrm{Y}, \mathrm{Zr} / \mathrm{Y}$, and Th (Figure 7B) also demonstrate striking similarities between primitive CAVAS lavas and primitive Mariana Arc lavas. $\mathrm{Ba}$, as expected, ranges, to higher values in the primitive CAVAS lavas than primitive MORB and, in contrast to the other elements listed immediately above, ranges to values as high as that defined by the primitive Papuan Arc lavas. As mentioned previously, there is no correlation between $\mathrm{Ba}$ and LOI which suggests that the $\mathrm{Ba}$ contents are the result of subduction additions and not alteration. Interestingly, the primitive CAVAS lavas have significantly lower concentrations of the HFSE ( $\mathrm{Zr}, \mathrm{Nb}, \mathrm{Hf})$ and the "subduction component indicators" $\mathrm{Sr}, \mathrm{Ba}$, and $\mathrm{Th}$, than the Papuan suite but much lower $\mathrm{Zr} / \mathrm{Y}$ which suggests that the former was either derived from a more depleted source or underwent higher degrees of partial melting than the latter.

In Figure 7C, I plot $\mathrm{SiO}_{2}$ vs. $\mathrm{Nb} / \mathrm{Yb}, \mathrm{Th} / \mathrm{Nb}, \mathrm{Ba} / \mathrm{Nb}$ and $\mathrm{Ba} / \mathrm{Th}$. $\mathrm{Nb} / \mathrm{Yb}, \mathrm{Ba} / \mathrm{Nb}$, and $\mathrm{Ba} / \mathrm{Th}$ show no correlation with $\mathrm{SiO}_{2}$ while $\mathrm{Th} / \mathrm{Nb}$ increases moderately. $\mathrm{Nb} / \mathrm{Yb}$ is a ratio of two fluidimmobile elements with different compatibilities and highlights mantle depletion (that is, $\mathrm{Nb} / \mathrm{Yb}$ decreases with increasing source depletion) (Pearce et al., 2005). $\mathrm{Ba} / \mathrm{Nb}, \mathrm{Th} / \mathrm{Nb}$, and $\mathrm{Ba} / \mathrm{Th}$ are proxies which gauge total, deep and shallow subduction inputs, respectively (Elliot et al., 1997; Pearce et al., 2005). Assuming that melting occurred in the spinel peridotite stability field, the lower $\mathrm{Nb} / \mathrm{Yb}$ of primitive CAVAS lavas relative to Mariana and Papuan arc lavas suggests either a more depleted source and/or higher degrees of melting of its source, which is consistent with variations in $\mathrm{Zr} / \mathrm{Y}$ which are generally lower for the primitive CAVAS suite. The primitive CAVAS lavas range to much higher $\mathrm{Ba} / \mathrm{Nb}, \mathrm{Th} / \mathrm{Nb}$, and $\mathrm{Ba} / \mathrm{Th}$ than the primitive Mariana Arc lavas which demonstrates a higher subduction component in the genesis of the former relative to the latter. $\mathrm{Ba} / \mathrm{Nb}$ and $\mathrm{Ba} / \mathrm{Th}$ are also higher in the primitive CAVAS suite relative to the primitive Papuan Arc lavas but Th/Nb is significantly lower in the CAVAS suite. This suggests that the CAVAS source received greater shallow but lesser deep subduction additions than the source responsible for the primitive Papuan Arc lavas.

Plots of $\mathrm{SiO}_{2}$ vs. gauges of fertility and/or degrees of partial melting such as $\mathrm{Nb} / \mathrm{Yb}$ and $\mathrm{Zr} / \mathrm{Y}$ (Figures 7B,C) demonstrate that the primitive Chagres-Bayano arc lavas were derived from either a more depleted source or underwent higher degrees of partial melting than primitive lavas of the Sona-Azuero and Golfito arc segments. These plots also demonstrate a more depleted source or higher degree of melting for all primitive 

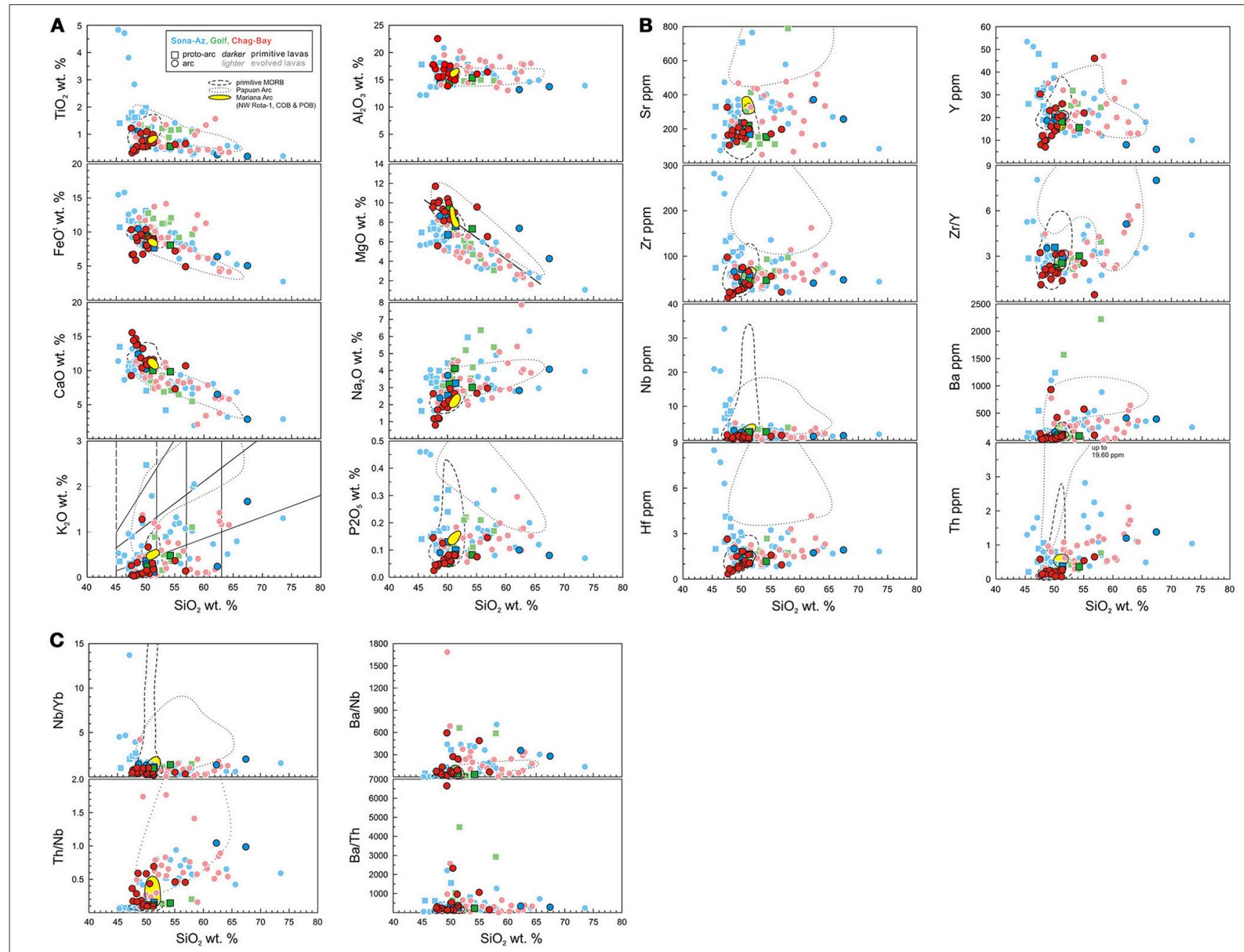

FIGURE 7 | $\mathrm{SiO}_{2}$ vs. (A) $\mathrm{TiO}_{2}, \mathrm{Al}_{2} \mathrm{O}_{3}, \mathrm{FeO}^{t}, \mathrm{MgO}, \mathrm{CaO}, \mathrm{Na}_{2} \mathrm{O}, \mathrm{K}_{2} \mathrm{O}$, and $\mathrm{P}_{2} \mathrm{O}_{5}$, (B) $\mathrm{Sr}, \mathrm{Y}, \mathrm{Zr}, \mathrm{Zr} / \mathrm{Y}, \mathrm{Nb}, \mathrm{Ba}$, $\mathrm{Hf}$, and Th and (C) $\mathrm{Nb} / \mathrm{Yb}$, Ba/Nb, Th/Nb, and Ba/Th, and $\mathrm{Th} / \mathrm{Nb}$ vs. Ba/Nb and $\mathrm{Nb} / \mathrm{Yb}$ of primitive and evolved lavas of Sona-Azuero, Golfito and Chagres-Bayano. Shown for comparison are the composition of primitive MORB and primitive lavas of the Marianas and Papuan arcs. Fields of primitive Atlantic and Pacific MORB glasses (Mg\# 60-68, MgO =6.70-9.69 wt. \%, $n=204$ ) are from Jenner and O'Neill (2012). Field for primitive lavas of the Mariana Arc are from Tamura et al. (2011) and fields for primitive lavas of the Papuan Arc are from Smith et al. (1997) and Smith (2013). On plots where the Mariana Arc field is covered by symbols, the field is entirely contained within the primitive MORB field.

CAVAS lavas relative to primitive arc lavas of the Papuan Arc, but a similar source to that of the Mariana Arc in the case of Sona-Azuero and Golfito; Chagres-Bayano extends to more depleted values (lower $\mathrm{Nb} / \mathrm{Yb}$ and $\mathrm{Zr} / \mathrm{Y}$ ) than primitive lavas of the Mariana Arc. In the Chagres-Bayano primitive basalts, $\mathrm{Nb} / \mathrm{Yb}$ and $\mathrm{Zr} / \mathrm{Y}$ range from 0.17 to 1.02 and 1.13 to 3.23 , respectively, whereas the Sona-Azuero record $\mathrm{Nb} / \mathrm{Yb}$ and $\mathrm{Zr} / \mathrm{Y}$ of $0.97-1.12$ and 2.81-3.62; the Golfito primitive basalt yield $\mathrm{Nb} / \mathrm{Yb}$ and $\mathrm{Zr} / \mathrm{Y}$ of $0.68-0.99$ and $2.21-2.54$, respectively.

\section{Subduction Contributions I: Constraints From N-MORB Normalized Plots of Primitive Lavas Normalized to 8 wt. \% MgO} Plotted on Figure 8 are: (A) N-MORB normalized patterns of four Sona-Azuero, two Golfito and 15 Chagres-Bayano primitive basalts; (B) N-MORB normalized patterns of the mean of all primitive basalts of Sona-Azuero $(n=6)$, Golfito $(n=3)$, and Chagres-Bayano $(n=17)$ arc segments normalized to 8 wt. \% $\mathrm{MgO}$; and (C-E) the mean N-MORB normalized patterns of the primitive Sona-Azuero, Golfito and Chagres-Bayano primitive suites normalized to $8 \mathrm{wt}$. \% $\mathrm{MgO}$ (shown in $\mathrm{B}$ ) highlighting the distinctive mantle, deep subduction and shallow subduction components as outlined by Pearce et al. (2005). Table 3 provides compositions of primitive lavas of Sona-Azuero, Golfito and Chagres-Bayano normalized to $8 \mathrm{wt}$ \% $\mathrm{MgO}$ and for comparison, the compositions of Mariana and Papuan arc primitive lavas normalized to $8 \mathrm{wt}$. $\% \mathrm{MgO}$.

In a given subduction system, shallow subduction input is characterized by elements which are mobile in low-temperature aqueous fluids. Such low-temperature mobile elements include $\mathrm{Ba}, \mathrm{Rb}, \mathrm{Sr}$ and $\mathrm{Pb}$. Alternatively, deep subduction is distinguished 


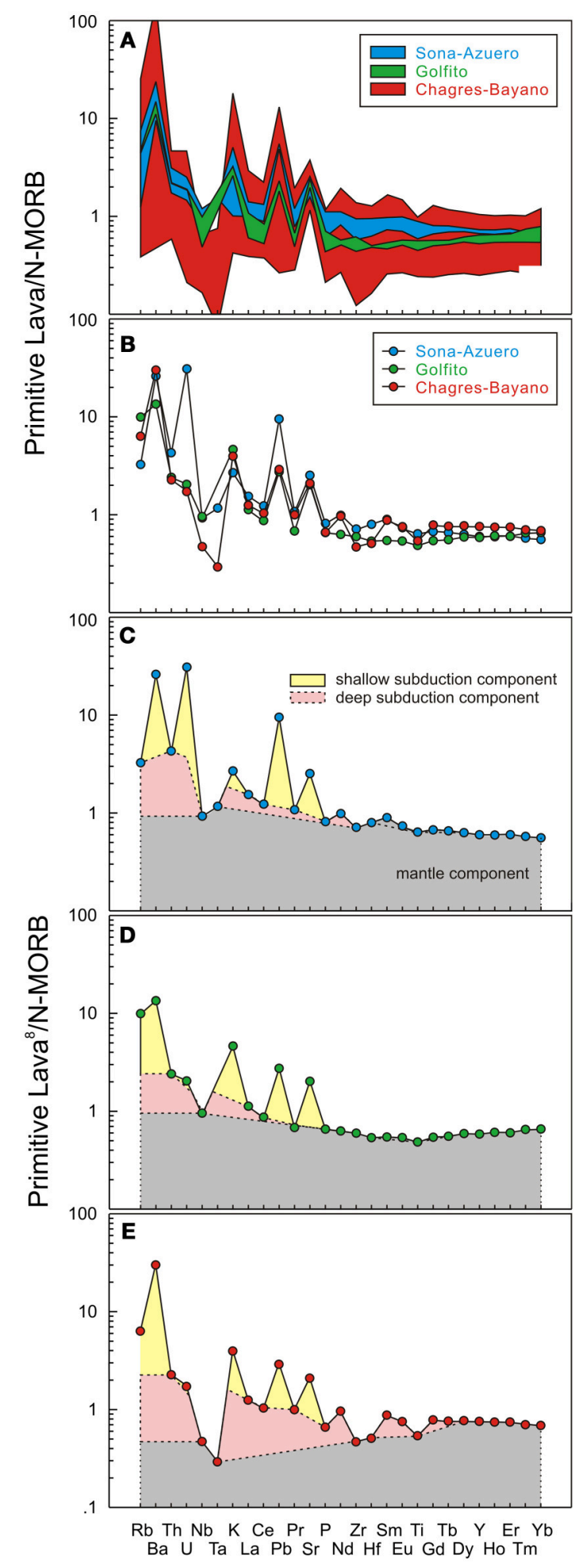

FIGURE 8 | N-MORB normalized plots of (A) four Sona-Azuero, two Golfito and fifteen Chagres-Bayano primitive basalts, (B) Sona-Azuero, Golfito and Chagres-Bayano lavas normalized to 8 wt. \% $\mathrm{MgO}$ and (C-E) the N-MORB normalized patterns of the primitive Sona-Azuero, Golfito and Chagres-Bayano suites normalized to $8 \mathrm{wt}$. \% MgO highlighting the distinctive mantle, deep subduction and shallow subduction components as suggested by Pearce et al. (2005). N-MORB concentrations are from Sun and McDonough (1989). by source enrichments in both this group of elements as well as the group of melt-mobile incompatible elements. These meltmobile elements include Th and the LREE, which are mobile at higher temperature or as a result of sediment melting (Pearce et al., 2005).

Perusal of Figure 8 suggests that the primitive ChagresBayano suite is the most enriched of the three suites in both shallow subduction and deep subduction components. This is verified in Figure 7C which shows that the primitive ChagresBayano lavas extend to higher $\mathrm{Ba} / \mathrm{Th}$ (shallow subduction gauge) and higher $\mathrm{Th} / \mathrm{Nb}$ (deep subduction gauge). $\mathrm{Ba} / \mathrm{Th}$ and $\mathrm{Th} / \mathrm{Nb}$ range from 117 to 6657 and 0.09 to 0.69 in the primitive Chagres-Bayano basalts whereas the primitive suite of ChagresBayano lavas normalized to $\mathrm{MgO}=8$ wt. \% records $\mathrm{Ba} / \mathrm{Th}$ and $\mathrm{Th} / \mathrm{Nb}$ of 691 and 0.25 (Table 3 ). In contrast, $\mathrm{Ba} / \mathrm{Th}$ and $\mathrm{Th} / \mathrm{Nb}$ range from a relatively modest $258-414$ and $0.11-0.15$ in the primitive Sona-Azuero basalts; the primitive suite of SonaAzuero lavas normalized to $\mathrm{MgO}=8 \mathrm{wt}$. \% yields $\mathrm{Ba} / \mathrm{Th}$ of 315 and $\mathrm{Th} / \mathrm{Nb}$ of 0.24 . Th concentrations are presented in one of two primitive Golfito basalts and records $\mathrm{Ba} / \mathrm{Th}$ of 352 and $\mathrm{Th} / \mathrm{Nb}$ of 0.11 , within the range of the primitive SonaAzuero basalts. Primitive Golfito lavas normalized to $8 \mathrm{wt}$. \% $\mathrm{MgO}$ record $\mathrm{Ba} / \mathrm{Th}$ of 294 and $\mathrm{Th} / \mathrm{Nb}$ of 0.13 (Table 3). Not surprisingly, the primitive Chagres-Bayano basalts also record the highest "total subduction component" with $\mathrm{Ba} / \mathrm{Nb}$ of $19-594$ and a normalized to $\mathrm{MgO}=8$ wt. $\% \mathrm{Ba} / \mathrm{Nb}$ of 171 . The suite of primitive Sona-Azuero and Golfito lavas record much lower $\mathrm{Ba} / \mathrm{Nb}$ ratios of $21-63$ and $40-62$ whereas the suite of primitive Sona-Azuero and Golfito lavas normalized to 8 wt. \% $\mathrm{MgO}$ yield $\mathrm{Ba} / \mathrm{Nb}$ of 75 and 38 , respectively. As the Chagres-Bayano arc segment began to form later (70-39 Ma) than those of the SonaAzuero (75-39 Ma) and Golfito (75-66 Ma) arc segments (Buchs et al., 2010; Wegner et al., 2011) and the three segments likely represent an originally contiguous system (Montes et al., 2012; Whattam and Stern, 2015), this suggests that the early CAVAS evolved from less to more subduction-modified compositions over time. Enrichment in these subduction components in the primitive Chagres-Bayano basalts relative to primitive basalts of the Sona-Azuero and Golfito complexes reflect a more extensive interaction of hydrous metasomatic fluids or melts which could also have resulted in higher degrees of melting in the ChagresBayano basalts relative to those of Sona-Azuero and Golfito as shown above.

Compared with primitive lavas of the Mariana and Papuan arcs, the early primitive CAVAS lavas exhibit greater shallow subduction components (as gauged by $\mathrm{Ba} / \mathrm{Th}$ ) than both Mariana and Papua but a lesser deep subduction component (as gauged by $\mathrm{Th} / \mathrm{Nb}$ ) than the Papuan Arc. Primitive lavas of the Mariana Arc record $\mathrm{Ba} / \mathrm{Th}$ and $\mathrm{Th} / \mathrm{Nb}$ of $160-189$ and $0.16-0.47$ whereas the Papuan Arc primitive lavas record $\mathrm{Ba} / \mathrm{Th}$ and $\mathrm{Th} / \mathrm{Nb}$ of $46-163$ and $0.33-3.01$.

\section{Subduction Contributions II: Constraints From $\mathbf{N b} / \mathrm{Yb}$ vs. M Plots}

Further insights into the relative contributions of slab-derived subduction zone fluids to the petrogenesis of the early 
TABLE 3 | Whole rock compositions of primitive CAVAS, MORB, Mariana Arc and Papuan Arc lavas normalized to 8 wt. \% MgO.

\begin{tabular}{|c|c|c|c|c|c|c|c|}
\hline Unit & $\begin{array}{c}\text { Sona-Azuero } \\
n=7\end{array}$ & $\begin{array}{c}\text { Golfito } \\
n=3\end{array}$ & $\begin{array}{l}\text { Chagres-Bayano } \\
\qquad n=17\end{array}$ & $\begin{array}{l}\text { MORB } \\
n=204\end{array}$ & $\begin{array}{c}\text { МА СОВ } \\
n=7\end{array}$ & $\begin{array}{c}\text { MA РОВ } \\
n=6\end{array}$ & $\begin{array}{c}\text { Papuan Arc } \\
n=34\end{array}$ \\
\hline \multicolumn{8}{|c|}{ MAJOR OXIDES (wt. \%) } \\
\hline $\mathrm{SiO}_{2}$ & 52.81 & 52.52 & 50.84 & 50.66 & 51.15 & 51.39 & 54.70 \\
\hline $\mathrm{TiO}_{2}$ & 0.80 & 0.61 & 0.69 & 1.28 & 0.79 & 0.89 & 1.18 \\
\hline $\mathrm{Al}_{2} \mathrm{O}_{3}$ & 15.01 & 15.19 & 17.36 & 16.15 & 16.37 & 16.61 & 15.22 \\
\hline $\mathrm{FeO}^{\mathrm{t}}$ & 8.71 & 8.62 & 7.68 & 9.08 & 8.60 & 8.11 & 6.92 \\
\hline $\mathrm{MnO}$ & 0.19 & 0.15 & 0.20 & NR & 0.16 & 0.16 & 0.12 \\
\hline $\mathrm{MgO}$ & 8.00 & 8.00 & 8.00 & 8.00 & 8.00 & 8.00 & 8.00 \\
\hline $\mathrm{CaO}$ & 9.92 & 10.11 & 11.74 & 11.92 & 11.33 & 10.87 & 7.75 \\
\hline $\mathrm{Na}_{2} \mathrm{O}$ & 3.02 & 3.44 & 2.27 & 2.55 & 2.00 & 2.41 & 3.48 \\
\hline $\mathrm{K}_{2} \mathrm{O}$ & 0.19 & 0.33 & 0.29 & 0.21 & 0.51 & 0.50 & 1.90 \\
\hline $\mathrm{P}_{2} \mathrm{O}_{5}$ & 0.09 & 0.08 & 0.08 & 0.15 & 0.14 & 0.15 & 0.43 \\
\hline Mg\# & 62 & 62 & 65 & 61 & 62 & 64 & 67 \\
\hline \multicolumn{8}{|c|}{ TRACE ELEMENTS (ppm) } \\
\hline $\mathrm{Cr}$ & 322.69 & 128.86 & 264.09 & 310.48 & 338.80 & 291.12 & 296.27 \\
\hline $\mathrm{Ni}$ & 83.83 & 72.00 & 97.59 & 120.49 & 100.62 & 112.21 & 88.18 \\
\hline $\mathrm{Rb}$ & 1.77 & 5.54 & 3.55 & 4.65 & 8.07 & 7.62 & 24.81 \\
\hline Sr & 227.32 & 181.30 & 188.68 & 141.16 & 344.96 & 316.35 & 773.89 \\
\hline Y & 16.78 & 16.38 & 21.27 & 24.16 & 17.40 & 20.44 & 23.90 \\
\hline $\mathrm{Zr}$ & 52.46 & 44.27 & 34.86 & 75.06 & 44.44 & 60.77 & 181.03 \\
\hline $\mathrm{Nb}$ & 2.17 & 2.22 & 1.10 & 6.43 & 1.32 & 3.12 & 7.33 \\
\hline $\mathrm{Ba}$ & 163.17 & 84.77 & 188.64 & 52.53 & 95.33 & 94.56 & 655.74 \\
\hline La & 3.82 & 2.80 & 3.12 & 5.24 & 5.51 & 5.38 & 58.98 \\
\hline $\mathrm{Ce}$ & 9.14 & 6.52 & 7.76 & 12.91 & 12.45 & 12.54 & 67.78 \\
\hline $\mathrm{Yb}$ & 1.70 & 2.01 & 2.09 & 2.65 & 1.57 & 1.91 & 2.37 \\
\hline $\mathrm{Hf}$ & 1.63 & 1.10 & 1.05 & 1.99 & 1.12 & 1.46 & 5.38 \\
\hline $\mathrm{Ta}$ & 0.15 & $N R$ & 0.04 & 0.36 & 0.10 & 0.16 & 0.60 \\
\hline $\mathrm{Pb}$ & 2.84 & 0.81 & 0.87 & 0.58 & 1.44 & 1.34 & 9.11 \\
\hline Th & 0.52 & 0.29 & 0.27 & 0.48 & 0.58 & 0.52 & 7.73 \\
\hline$U$ & 1.49 & 0.10 & 0.08 & 0.14 & 0.22 & 0.19 & 1.43 \\
\hline V & 257.92 & 230.57 & 225.98 & 265.59 & 297.40 & 280.79 & 207.88 \\
\hline $\mathrm{Nb} / \mathrm{Yb}$ & 1.27 & 1.11 & 0.53 & 2.43 & 0.84 & 1.63 & 3.09 \\
\hline $\mathrm{Zr} / \mathrm{Y}$ & 3.13 & 2.70 & 1.64 & 3.11 & 2.55 & 2.97 & 7.57 \\
\hline $\mathrm{Ba} / \mathrm{Th}$ & 315.18 & 294.23 & 690.98 & 108.65 & 164.88 & 182.30 & 84.82 \\
\hline $\mathrm{Th} / \mathrm{Nb}$ & 0.24 & 0.13 & 0.25 & 0.08 & 0.44 & 0.17 & 1.05 \\
\hline $\mathrm{Ba} / \mathrm{Nb}$ & 75.22 & 38.10 & 171.08 & 8.17 & 72.31 & 30.35 & 89.46 \\
\hline
\end{tabular}

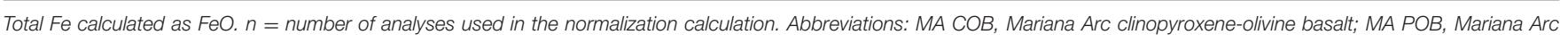

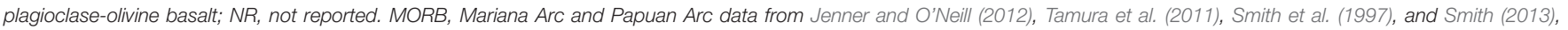
respectively.

CAVAS lavas can be obtained with plots of $\mathrm{M} / \mathrm{Yb}$ vs. $\mathrm{Nb} / \mathrm{Yb}$ (Pearce and Peate, 1995) where M represents the element under study. In such plots, $\mathrm{Nb}$ is widely thought to be least effectively transferred from the slab to the mantle wedge melting region (Pearce and Peate, 1995; Peate et al., 1997). According to Pearce and Peate (1995), if adding from the slab a variable $M$ to a mantle wedge source of constant composition, samples will displace from the MORB array to higher $\mathrm{M} / \mathrm{Yb}$ ratios and form a vertical trend at given $\mathrm{Nb} / \mathrm{Yb}$, or plot within the MORB array. Following Pearce et al. (1995), the subduction contribution is quantified by contour lines drawn vertically upward, paralleling the MORB array (Figure 9). The MORB array in this study is as defined by Xia et al. (2012) but essentially defines oceanic basalts. As can be seen in Figure 9, primitive and evolved basalt samples from the Sona-Azuero and Golfito complexes mostly plot within the MORB array and form a pseudo-linear trend that passes through the average N-MORB to average E-MORB composition, suggesting that the mantle contributes $\sim 75 \%$ of $\mathrm{Nd}$, Zr, and Th ( 6-8 samples out of a total of 24 plot above the array), and nearly $100 \%$ of La through the peridotite melting process in the case of Sona-Azuero. In contrast, the compositions of the primitive Chagres-Bayano basalts are instead vertically offset to values much higher than the MORB array, suggesting significant contributions of these elements via slab-derived fluids. 


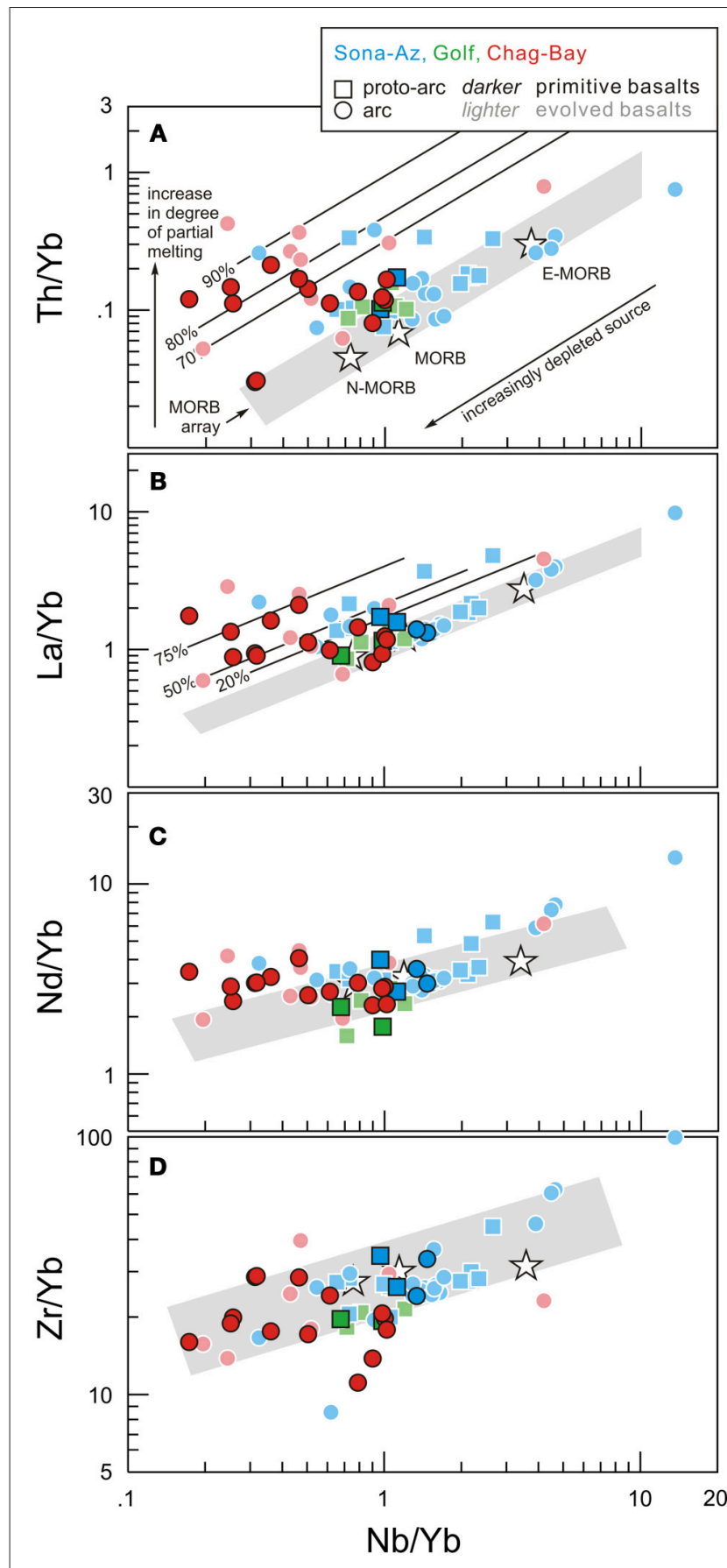

FIGURE 9 | Comparison of early CAVAS primitive and evolved basalts vs. ocean floor basalts which define the MORB array (see Xia et al., 2012), intra-oceanic arc rocks (Kelemen et al., 2003) and boninites (see Xia et al., 2012 for references) of Cape Vogel (Papua-New Guinea), Site 786 (Izu-Bonin forearc) and Dachadaban (China) in Nb/Yb vs. (A) Th/Yb, (B) La/Yb, (C) Nd/Yb and (D) $\mathrm{Zr} / \mathrm{Yb}$ space. The solid parallel lines in $\mathbf{( A , B )}$ with percentages indicated represent contours of percentage of subduction zone contributions for the particular element [for example, Th in (A) and La in (B)] in the mantle (Pearce et al., 1995; see text for further explanation). Average N-MORB and MORB values are from Arévalo and McDonough (2010) and the E-MORB value is from Sun and McDonough (1989). Abbreviations: Chag-Bay, Chagres-Bayano; DCDB, Dachadaban; Golf, Golfito IOA, intra-oceanic arc; Sona-Az, Sona-Azuero.
For example, the subduction contributions of Th range from $<70$ to $90 \%$ for the primitive Chagres-Bayano basalts and in excess of $90 \%$ for the evolved Chagres-Bayano basalts whereas the subduction contributions of La range from 20 to $>75 \%$ for the primitive and evolved Chagres-Bayano basalts (Figure 9). Also of significance, and as noted earlier, is the difference in $\mathrm{Nb} / \mathrm{Yb}$ between the Sona-Azuero and Golfito complexes and the Chagres-Bayano complex. Basalts of the Chagres-Bayano complex exhibit significantly lower $\mathrm{Nb} / \mathrm{Yb}$ than those of the Sona-Azuero and Golfito complexes suggesting either a higher degree of melting or tapping of a more depleted source in the case of the former. Whereas the Sona-Azuero and Golfito lavas are consistent with tapping of a source intermediate to $\mathrm{N}$ - and E-MORB, the Chagres-Bayano lavas are instead consistent with partial melting of a source significantly more depleted source than N-MORB.

\section{Comparison With Global Primitive Arc Melts}

A study of a large dataset $(n=938)$ of primitive arc melts from 30 continental and oceanic arc systems (Schmidt and Jagoutz (2017) recognized six principle primitive arc melt types: calcalkaline basalts and andesites; tholeiitic basalts; highly depleted tholeiitc andesites; shoshonites; and low-Si basalts. On the basis of $\mathrm{K}_{2} \mathrm{O}$ vs. $\mathrm{SiO}_{2}$ relations (Figure 10) the mean composition of Sona-Azuero, Golfito and Chagres-Bayano are analogous to depleted tholeiitic andesites, tholeiitic arc basalts to calc-alkaline andesites, and tholeiitic arc basalts, respectively. These mean compositions generally agree with the AFM (total-alkalis, $\mathrm{FeO}^{\mathrm{t}}$, $\mathrm{MgO}$ ) plot (Supplementary Figure 3). Approximately half of the Sona-Azuero primitive and evolved samples plot within the tholeiitic field; apart from one MgO-rich primitive sample, the remaining primitive samples plot within the calc-alkaline field. A similar trend is seen for Golfito. The Chagres-Bayano primitive magmas plot almost completely within the tholeitic field whereas approximately half of the evolved samples show an Fe-enrichment trend and the other half plot within the calcalkaline field.

In terms of $\mathrm{SiO}_{2}$ vs. $\mathrm{MgO}, \mathrm{CaO}, \mathrm{TiO}_{2}$, and $\mathrm{Na}_{2} \mathrm{O}$ (Supplementary Figure 4), global tholeiitic and calc-alkaline oceanic arc basalts show great overlap with each other and depleted tholeiitic andesites plot uniquely due to their higher $\mathrm{SiO}_{2}$ contents. Despite the overlap between tholeiitic and calcalkaline basalts a broad observation is that primitive magmas of all three complexes plot within the tholeiitic and calcalkaline fields. Again, this is consistent with the AFM plot (Supplementary Figure 3).

Schmidt and Jagoutz (2017) also plotted average ( $\mathrm{Rb}_{\mathrm{PMN}}$, BapMN, ThPMN, U UMN, where PMN is primitive mantlenormalized, PM values from Sun and McDonough, 1989) vs. $\mathrm{K}_{2} \mathrm{O}$ (Figure 11) to assess slab-derived contributions of LILE. Relatively good correlations are shown by the global oceanic tholeiitic arc basalts and calc-alkaline basalts. Although there is no correlation shown by Azuero and Golfito magmas $\left(R^{2}\right.$ of 0.07 and 0.18 , respectively), excellent correlation is shown by the Chagres-Bayano primitive magmas $\left(R^{2}=0.85\right)$. The reason for 

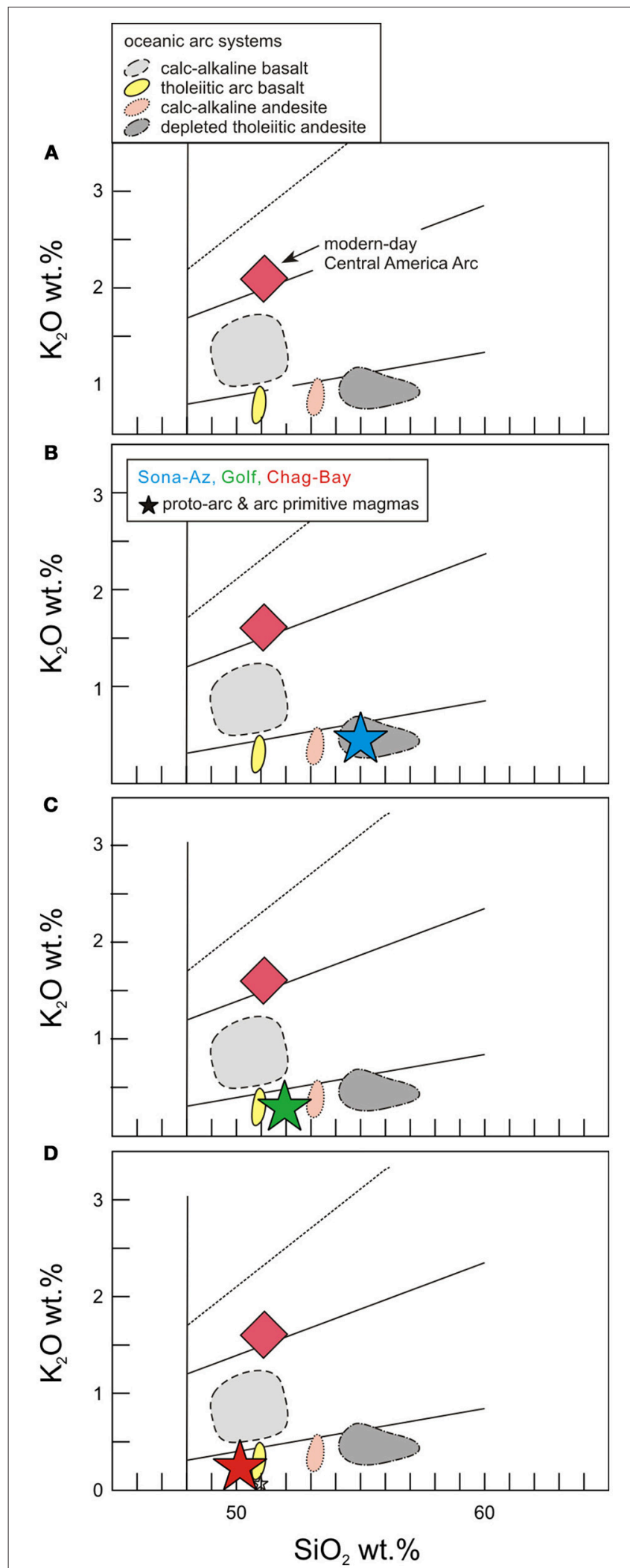

FIGURE 10 | $\mathrm{K}_{2} \mathrm{O}$ vs. $\mathrm{SiO}_{2}$ for primitive lavas of (A) the Central American Arc, (B) the Sona-Azuero Arc, (C) the Golfito Arc and (D) the Chagres-Bayano Arc. Fields for the oceanic arc systems are from Schmidt and Jagoutz (2017).

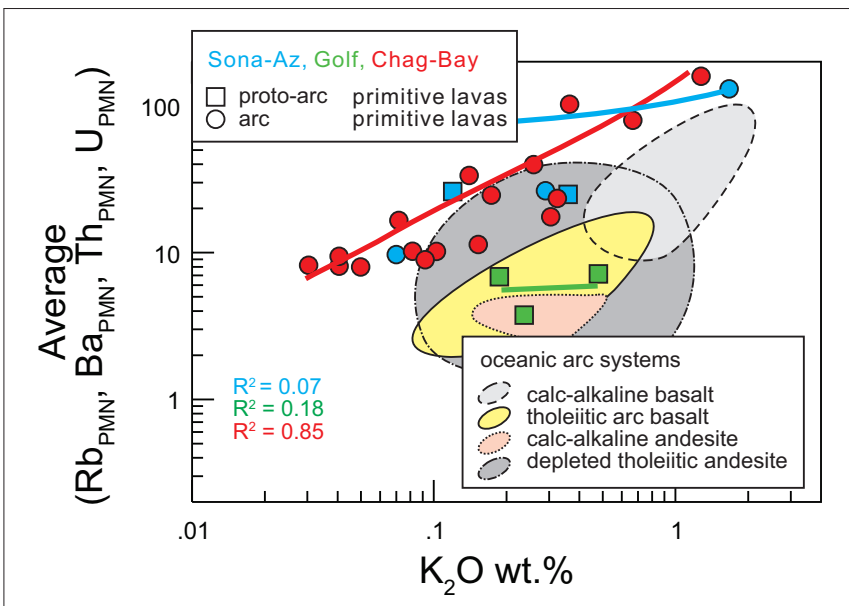

FIGURE 11 | Average primitive mantle-normalized LILE (Rb, Ba, Th, U) vs. $\mathrm{K}_{2} \mathrm{O}$ for primitive Sona-Azuero, Golfito and Chagres-Bayano magmas vs. those of oceanic arc systems (Schmidt and Jagoutz, 2017). Abbreviations: Sona-Az, Sona-Azuero; Golf, Golfito; Chag-Bay, Chagres-Bayano.

the lack of correlation shown by Azuero and Golfito primitive magmas may simply be the small sample set $(n=5$ and 3 for Azuero and Golfito, respectively, whereby Chagres-Bayano has 17 samples). The excellent correlation between average ( $\mathrm{Rb}_{\mathrm{PMN}}$, BapMN, ThPMN, $\mathrm{U}_{\mathrm{PMN}}$ ) and $\mathrm{K}_{2} \mathrm{O}$ exhibited by Chagres-Bayano suggests that these LILE ( $\mathrm{Rb}, \mathrm{Ba}, \mathrm{Th}, \mathrm{U})$ were derived from the subducting slab.

\section{Mantle Potential Temperature}

Potential mantle temperature estimates were calculated with PRIMELT3 (Herzberg and Isamow, 2015) and the method of Putirka (2008). In the former case, using $\mathrm{Fe}^{2+} / \mathrm{Fe}^{\mathrm{T}}$ of 0.85 and 0.90 , all primitive basalts yielded $\mathrm{Tp}$ of $<1,305^{\circ} \mathrm{C}$ which is consistent with ambient and not anomalously hot mantle. In the latter case, similar results were obtained but for the identical calculations of $1,633 \pm 47^{\circ} \mathrm{C}$ for two Sona-Azuero samples (DB05-087 and DB06-112) (Buchs et al., 2010).

The "success" of the these two high Tp may be due to the fact that these two lavas were derived largely from DMM and HIMU mantle rather than from a subductionmodified source; i.e., their formation may have occurred early in the subduction process before influences from the sinking/subducting slab became prominent. An age determination would help confirm this hypothesis but unfortunately is unavailable.

\section{Plume-Subduction Interaction and Tectonic Considerations}

Smith et al. (1997) argued that high-Mg arc magmas can breach the crust only in unusual tectonic circumstances and used the Papuan Arc to illustrate this. In the case of the Papuan Arc, impingement of seafloor spreading in the Woodlark Basin upon the Papuan Arc resulted in a unique extensional tectonic regime unlike most volcanic arc systems (Smith et al., 1997; Smith, 2013). Other studies also emphasize the role 
of an extensional environment and/or thermal anomaly in generating primitive lavas. For example, Bacon et al. (1997) list numerous pieces of evidence to suggest that the uppermost mantle beneath the Cascades of the northwestern US which are responsible for primitive, high-Mg lavas of various volcanic fields of the Cascades Arc is anomalously hot. A hot subarc mantle beneath the Cascades is consistent with the young age of the subducting slab, high heat flow (Blackwell et al., 1990), and an extensional environment (Rogers, 1985) of the southern Washington to northern California segment of the Cascades Arc system. Such lithospheric extension, similar to that posited for the Papuan Arc, is consistent with mantle upwelling and, according to Bacon et al. (1997), promotes escape of primary magmas. Similarly, subduction-related highMg primitive basalts of southern Sardinia, Italy are ones which formed during crustal thinning within an extension-dominated tectonic setting (Mattioli et al., 2000). In the case of the Sardinian high-Mg magmatism, the extensional deformation and related complex tectonic features have been invoked as a cause for rapid breaching of the crust of primitive magmas (Mattioli et al., 2000). In the Lamongan Volcanic Field of the Sunda Arc, Indonesia, extensional tectonics has created conditions that promoted the rapid ascent of parental magmas (Carn and Pyle, 2001). A myriad of other studies have emphasized the relation between extensional tectonics in volcanic arcs and the eruption of lavas with primitive chemical characteristics (e.g., Luhr and Carmichael, 1981; Knittel and Oles, 1995). In such settings, the development of thinned and fractured crust allows rising magma to erupt at the surface at a relatively unmodified state, rather than ponding at the crust-mantle boundary. The rapid passage to the surface of individual magma batches inhibits the formation of long-lived crustal magma chambers and invariably leads to the formation of monogenetic vent fields comprising tens to thousands of individual eruptive centers, for example, cinder cones and maars, in these environments (e.g., the MichoacánGuanajuato Volcanic Field, Mexico, Luhr, 1997 and the Macolod Corridor, Philippines, Knittel and Oles, 1995).

To my knowledge, the role of extension is not known in the case of the early CAVAS, but the presence of a sub-arc thermal anomaly at the time of CAVAS establishment is well known. For example, picrites and komatities which require melting of high temperature material ascending within plume conduits comprise numerous segments of the CLIP in Costa Rica (Alvarado et al., 1997), western Columbia (Kerr et al., 1996a, 2002; Arndt et al., 1997; Serrano et al., 2011) and Curaçao (Kerr et al., 1996b; Sinton et al., 1998). Modern-day picrites are derived from mantle with a potential temperature up to $250^{\circ} \mathrm{C}$ hotter than that which yields MORB (see Hill et al., 1992) and komatiites are derived from even hotter mantle (Campbell et al., 1989; Arndt, 2003). On the basis of petrological modeling, Herzberg and Gazel (2009) demonstrated that the Galapagos Plume, responsible for CLIP formation, had potential temperatures of $1,560-1,620^{\circ} \mathrm{C}$ in the Cretaceous. Similarly, Hastie and Kerr (2010) showed that primary magmas of the CLIP in Curaçao had $\sim 20 \% \mathrm{MgO}$ and were derived from 30 to $32 \%$ partial melting of a fertile peridotite, the source region of which had a potential temperature of $1,564-1,614^{\circ} \mathrm{C}$. CLIP lavas thus were derived from decompression melting of a hot, upwelling mantle plume with excess heat relative to ambient mantle and thus, an unusually hot sub-arc mantle existed immediately preceding and overlapping SI. According to Tatsumi and Maruyama (1989), high geothermal gradients in the mantle wedge resulting from back-arc basin opening and subduction of relatively young and hot oceanic lithosphere can result in the partial melting of hydrous peridotites at shallow levels in the sub-forearc mantle wedge and the production of primary high magnesium andesites. In the case of Central America, it is clear that emplacement of the CLIP substantially raised geothermal gradients in the subarc mantle wedge which could have facilitated partial melting of hydrous peridotite to generate the early CAVAS primitive magmas. Furthermore, on the basis of thermodynamic modeling, Gerya et al. (2015) demonstrated that plume-induced subduction initiation (PISI) results in mechanical weakening and thinning of the lithosphere. All of the aforementioned factors would facilitate either primitive magma formation or their rapid ascent through the crust.

It is well known that there exists a chemical, isotopic and temporal relation between the CLIP and early CAVAS products (e.g., Hauff et al., 2000a; Hoernle et al., 2004; Wegner et al., 2011) suggesting a genetic link between the two. These studies demonstrate an almost complete overlap in terms of $\mathrm{Pb}$ and $\mathrm{Nd}$ between early primitive CAVAS lavas and those of the CLIP and Galapagos Plume.

Via plots of ${ }^{143} \mathrm{Nd} /{ }^{144} \mathrm{Nd}$ vs. ${ }^{206} \mathrm{~Pb} /{ }^{204} \mathrm{~Pb}$ and ${ }^{207} \mathrm{~Pb} /{ }^{204} \mathrm{~Pb}$, Allibon et al. (2008) showed that formation of Late Cretaceous to Paleocene arc sequences along western Ecuador required three component mixing of depleted MORB mantle (DMM, East

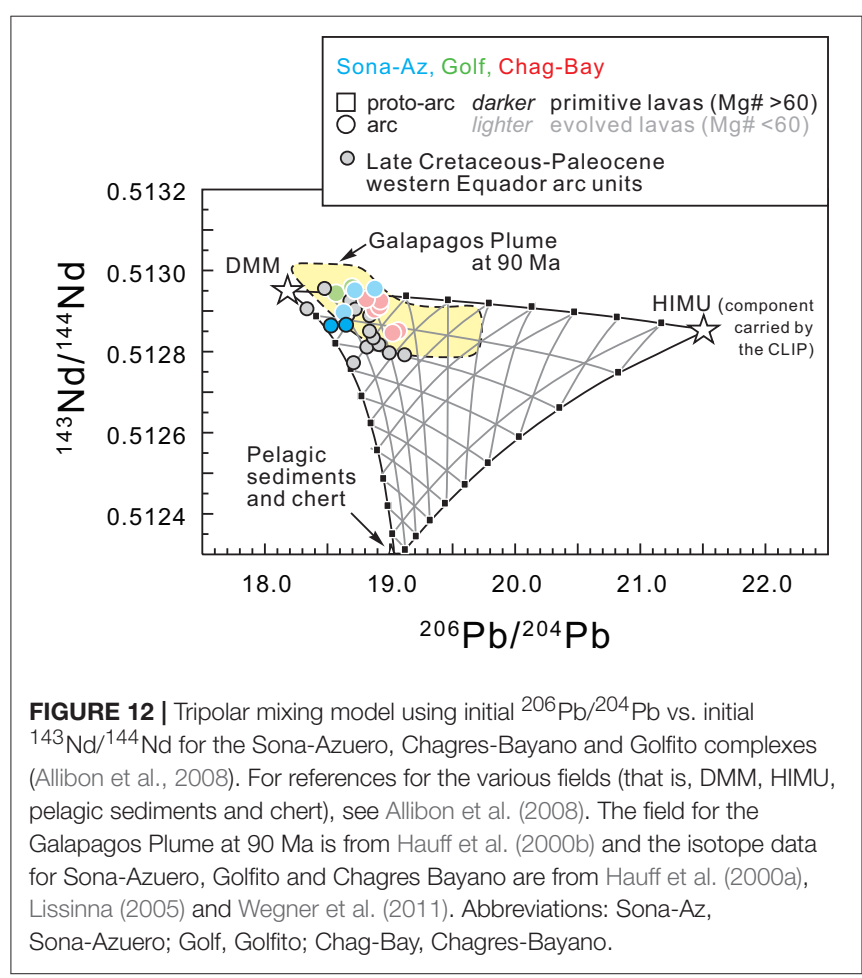


Pacific Cretaceous MORB), HIMU (carried by the CLIP) and an enriched, slab-derived pelagic sediment and chert component. These Ecuadorian arc sequences are ones considered by Whattam and Stern (2015) to represent the same plume-induced volcanic arc activity as in Central America. Using the ${ }^{143} \mathrm{Nd} /{ }^{144} \mathrm{Nd}$ vs. ${ }^{206} \mathrm{~Pb} /{ }^{204} \mathrm{~Pb}$ plot of Allibon et al. (2008), I show in Figure 12 that formation of both CAVAS lavas and the CLIP require mixing of the same three components. Allibon et al. (2008) suggested that an average contribution of 12-15\% HIMU, 7-15\% sediments and chert and $70-75 \% \mathrm{DMM}$ is required to explain the $\mathrm{Pb}$ and $\mathrm{Nd}$ isotopic values. Allibon et al. (2008) further suggested that an anomalously high thermal regime responsible for such high proportions of HIMU was likely inherited from the CLIP which supports the idea of an elevated thermal regime at subduction inception.

In addition to melting of the mantle, arrival of the CLIP plume head and an anomalously hot sub-arc mantle beneath the burgeoning CAVAS (Figure 13) could help explain the ascent of primitive magmas directly from the asthenosphere (Figure 13). Moreover, in other cases the arrival of a plume head has been invoked as a direct cause of crustal weakening and lithospheric extension (Hill et al., 1992) and the production of primitive lavas. For example, arrival of the Yellowstone Plume at 16$15 \mathrm{Ma}$ has been invoked as the trigger for lithospheric extension accompanying eruption of the Columbia River Flood Basalts (Parsons et al., 1994; Hooper, 1997). I suggest that arrival of the Galapagos head plume at the base of the Farallon Plate led to lithospheric extension in addition to mechanical weakening and thinning of the lithosphere (Gerya et al., 2015) which allowed for production and rapid ascent of a high percentage of primitive magmas which comprise the early CAVAS. It is also noteworthy that such a model is consistent with either a collision-induced (Buchs et al., 2010) or PISI scenario (Figure 13, Whattam and Stern, 2015).

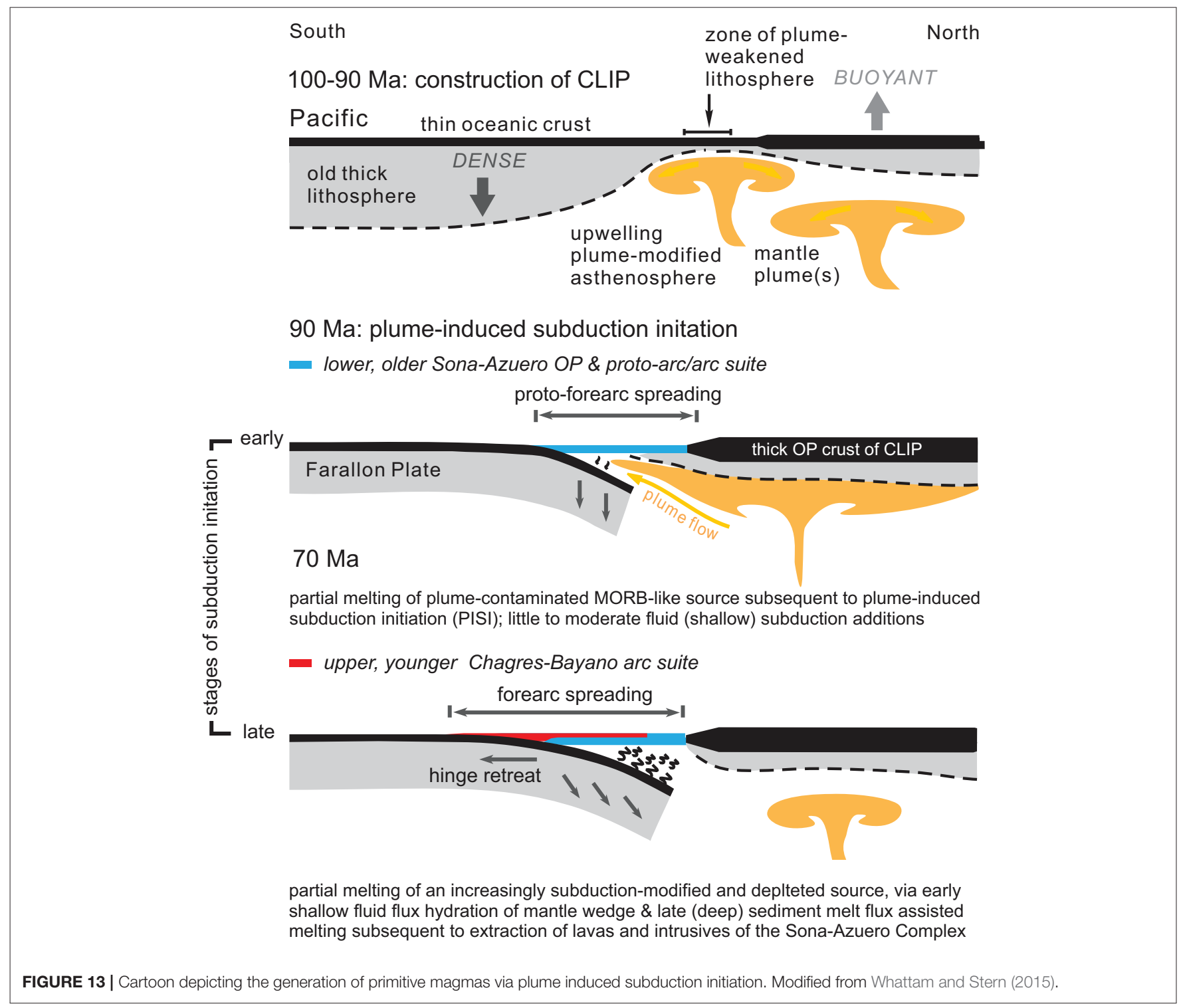




\section{CONCLUSIONS}

Primitive lavas with $\mathrm{Mg} \geq 60$ and concentrations of $\mathrm{Ni}$ and $\mathrm{Cr}$ extending to greater than $300 \mathrm{ppm}$ and $700 \mathrm{ppm}$, respectively, are identified from the Sona-Azuero, Golfito and Chagres-Bayano arc segments of the early (75-39 Ma) CAVAS. Radiometric ages are limited but production of primitive magmas appears to be restricted to between 71 and $66 \mathrm{Ma}$ but other considerations suggests SI circa $89 \mathrm{Ma}$ which suggests primitive magma production for circa $20 \mathrm{~m}$.y. In terms of major element abundances, the early CAVAS primitive lavas are very similar to primitive MORB and primitive arc basalts of the Mariana Arc system. In terms of most trace elements, the early CAVAS primitive lavas are also similar to those of the Mariana Arc and to global intra-oceanic arc tholeiitc basalts and calc-alkaline basalts. With respect to subduction components, primitive basalts of Chagres-Bayano exhibit evidence of significantly higher shallow and deep subduction components as gauged by $\mathrm{Ba} / \mathrm{Th}$ and $\mathrm{Th} / \mathrm{Nb}$ than primitive basalts of Sona-Azuero and Golfito. A plot of average ( $\mathrm{Rb}_{\mathrm{PMN}}$, BapMN, ThPMN, UPMN) vs. $\mathrm{K}_{2} \mathrm{O}$ demonstrates that these LILE (Rb, Ba, Th, U) were derived from the subducted slab in the case of the Chagres-Bayano complex.

As has been shown in previous studies, early CAVAS lavas are remarkably similar in isotopic composition to those of the CLIP oceanic plateau. In ${ }^{143} \mathrm{Nd} /{ }^{144} \mathrm{Nd}$ vs. ${ }^{206} \mathrm{~Pb} /{ }^{204} \mathrm{~Pb}$ space, almost all primitive and evolved lavas of the early CAVAS segments in Sona-Azuero, Golfito and Chagres-Bayano plot within the fields defined by the Galapagos Plume at 90 Ma. All early CAVAS lavas are consistent with formation from a source composed of three principal components: depleted MORB mantle (DMM), a HIMU component carried by the CLIP, and subducted pelagic sediments and chert. These isotopic similarities between plume and arc lavas are consistent with subduction-plume interaction

\section{REFERENCES}

Allibon, J., Monjoie, P., Lapierre, H., Jaillard, E., Bussy, F., Bosch, D., et al. (2008). The contribution of the young Cretaceous Caribbean Oceanic Plateau to the genesis of late Cretaceous arc magmatism in the Cordillera Occidental of Ecuador. J. South Am. Earth Sci. 26, 355-368. doi: 10.1016/j.jsames.2008. 06.003

Alvarado, G. E., Denyer, P., and Sinton, C. W. (1997). The 89 Ma Tortugal komatiitic suite, Costa Rica: implications for a common geological origin of the Caribbean and Eastern Pacific region from a mantle plum. Geology 25, 439-442. doi: 10.1130/0091-7613(1997)025\&lt;0439:TMTKSC\&gt;2.3.CO;2

Arculus, R. J. (1994). Aspects of magma genesis in arcs. Lithos 33, 189-208. doi: 10.1016/0024-4937(94)90060-4

Arévalo, R. Jr., and McDonough, W. F. (2010). Chemical variations and regional diversity observed in MOR. Chem. Geol. 271, 70-85. doi: 10.1016/j.chemgeo.2009.12.013

Arndt, N. T. (2003). Komatiites, kimberlites and boninites. J. Geophys. Res.108, 2293. doi: 10.1029/2002JB002157

Arndt, N. T., Kerr, A. C., and Tarney, J. (1997). Dynamic melting in plume heads: the formation of Gorgona komatiites and basalts. Earth Planet Sci. Lett. 146, 289-301. doi: 10.1016/S0012-821X(96)00219-1

Bacon, C. R., Bruggman, P. E., Christiansen, R. L., Clynne, M. A., Donnelly-Nolan, J. M., and Hildreth, W. (1997). Primitive magmas at five Cascade volcanic fields: melts from hot, heterogeneous sub-arc mantle. Can. Mineral.35, 397-423.

Baker, M. B., Grove, T. L., and Price, R. (1994). Primitive basalts and andesites of the Mt. Shasta region, N. California: products of varying melt fraction and water content. Contrib. Mineral. Petrol. 118, 111-129. doi: 10.1007/BF01052863 regardless of whether subduction inception was collision- or plume-induced.

Subduction-plume interaction also dictates that an elevated sub-arc thermal anomaly was present at inception of the CAVAS. Evidence of an elevated thermal anomaly are provided by high-MgO picrites and komatiites which comprise integral components of the CLIP, as they require high temperatures $\left(>1,550^{\circ} \mathrm{C}\right)$ of formation. Relatedly, potential temperatures of $1,633 \pm 47^{\circ} \mathrm{C}$ were calculated for two Sona-Azuero samples, which suggest the existence of anomalously hot mantle during early SI. I suggest that, in addition to providing an anomalously high temperature regime in the sub-arc mantle at inception of the CAVAS, extrusion of the CLIP oceanic plateau also resulted in lithospheric weakening and extension which allowed for production and rapid ascent of primitive magmas which comprise the early CAVAS.

\section{AUTHOR CONTRIBUTIONS}

The author confirms being the sole contributor of this work and approved it for publication.

\section{ACKNOWLEDGMENTS}

SW acknowledges financial support from the Smithsonian Tropical Research Institute, Balboa, Ancon, Panama during his postdoctoral tenure there.

\section{SUPPLEMENTARY MATERIAL}

The Supplementary Material for this article can be found online at: https://www.frontiersin.org/articles/10.3389/feart. 2018.00114/full\#supplementary-material

Bartels, K. S., Kinzler, R. J., and Grove, T. L. (1991). High-pressure phase relations of primitive high-alumina basalts from Medecine Lake Volcano, northern California. Contrib. Mineral. Petrol. 108, 253-270. doi: 10.1007/BF00285935

Barth, M. G., McDonough, W. F., and Rudnick, R. L. (2000). Tracking the budget of $\mathrm{Nb}$ and $\mathrm{Ta}$ in the continental crust. Chem. Geol. 165, 197-213, doi: 10.1016/S0009-2541(99)00173-4

Blackwell, D. D., Steele, J. L., Frohme, M. K., Murphey, C. F., Priest, G. R., and Black, G. L. (1990). Heat flow in the Oregon Cascade Range and its correlation with regional gravity, Curie Point depths, and geology. J. Geophys. Res. 95, 19475-19493. doi: 10.1029/JB095iB12p19475

Buchs, D. M., Arculus, R. J., Baumgartner, P. O., Baumgartner-Mora, C., and Ulianov, A. (2010). Late Cretaceous arc development on the SW margin of the Caribbean Plate: insights from the Golfito, Costa Rica, and Azuero, Panama, complexes. Geochem. Geophys. Geosyst. 11:Q07S24. doi: 10.1029/2009GC002901

Cameron, W. E. (1985). Petrology and origin of primitive lavas from the Trodoos ophiolite, Cyprus. Contrib. Mineral. Petrol. 89, 239-255. doi: 10.1007/BF00379457

Campbell, I. H., Griffiths, R. W., and Hill, R. I. (1989). Melting in an Archaean mantle plume: head's it's basalts, tails it's komatiites. Nature 339, 697-699.

Carn, S. A., and Pyle, D. M. (2001). Petrology and geochemistry of the Lamongan volcanic field, East Java, Indonesia: primitive Sunda Arc magmas in an extensional tectonic setting? J. Petrol. 42, 1643-1683. doi: 10.1093/petrology/42.9.1643

Crawford, A. J., Falloon, T. J., and Eggins, S. (1987). The origin of island arc high-alumina basalts. Contrib. Mineral. Petrol. 97, 417-430. doi: 10.1007/BF00372004 
Draper, D. S., and Johnson, A. D. (1992). Anhydrous PT phase relations of an Aleutian high-MgO basalt: an investigation of the role of olivine-liquid reaction in the generation of arc high-alumina basalts. Contrib. Mineral. Petrol. 112, 501-519. doi: 10.1007/BF00310781

Eggins, S. M. (1993). Origin and differentiation of picritic arc magmas, Ambae (Aoba), Vanuatu. Contrib. Mineral. Petrol. 114, 79-100. doi: 10.1007/BF00307867

Elliot, T., Plank, T., Zindler, A., White, W., and Bourdon, B. (1997). Element transport from slab to volcanic front at the Mariana arc. J. Geophys. Res. 102, 14991-15019. doi: 10.1029/97JB00788

Gazel, E., Hayes, J. L., Hoernle, K., Kelemen, P., Everson, E., Holbrook, W. S., et al. (2015). Continental Crust generated in oceanic arcs. Nat. Geosci. 8, 321-327. doi: 10.1038/ngeo2392

Gerya, T. V., Stern, R. J., Baes, M., Sobolev, S. V., and Whattam, S. A. (2015). Plate tectonics on the Earth triggered by plume-induced subduction initiation. Nature 527, 221-225. doi: 10.1038/nature 15752

Gust, D. A., and Perfit, M. R. (1987). Phase relations of a high-Mg basalt from the Aleutian island arc: implications for primary island arc basalts and high-Al basalts. Contrib. Mineral. Petrol. 97, 7-18. doi: 10.1007/BF00375210

Hastie, A. R., and Kerr, A. C. (2010). Mantle plume or slab window? Physical and geochemical constraints on the origin of the Caribbean oceanic plateau. Earth-Science Reviews 98, 283-293. doi: 10.1016/j.earscirev.2009.11.001

Hauff, F., Hoernle, K., Tilton, G., Graham, D. W., and Kerr, A. C. (2000b). Large scale recycling of oceanic lithosphere over short time scales: geochemical constraints from the Caribbean Large Igneous Province. Earth Planet. Sci. Lett. 174, 247-263. doi: 10.1016/S0012-821X(99)00272-1

Hauff, F., Hoernle, K., van den Bogaard, P., Alvarado, G., and Garbe-Schönberg, D. (2000a). Age and geochemistry of basaltic complexes in western Costa Rica: contributions to the geotectonic evolution of Central America. Geochem. Geophys. Geosyst. 1:1999GC000020. doi: 10.1029/1999GC000020

Hawkesworth, C. J., Gallagher, K., Hergt, J. M., and McDermott, F. (1993a). Mantle and slab contributions in arc-magmas. Annu. Rev. Earth Planet. Sci. 21, 175-204. doi: 10.1146/annurev.ea.21.050193.001135

Hawkesworth, C. J., Gallagher, K., Hergt, J. M., and McDermott, F. (1993b). Trace element fractionation processes in the generation of island arc basalts. Philos. Trans. R. Soc. A Mat. Phys. Eng. Sci. 342, 179-191. doi: 10.1098/rsta.1993.0013

Herzberg, C., and Gazel, E. (2009). Petrological evidence for secular cooling in mantle plumes. Nature 458, 619-622. doi: 10.1038/nature07857

Herzberg, C., and Isamow, P. D. (2015). PRIMELT3 Mega.XLSM software for primary magma caclculation: peridotite primary magma $\mathrm{MgO}$ contents from the liquidus to the solidus. Geochem. Geophys. Geosyst. 16, 563-578. doi: 10.1002/2014GC005631

Hill, R. I., Campbell, H., Davies, G. F., and Griffiths, R. W. (1992). Mantle plumes and continental tectonics. Science 256, 186-193. doi: $10.1126 /$ science. 256.5054 .186

Hochstaedter, A. G., Kepezhinskas, P., Defant, M., Drummond, M. J. B., Murakami, F., and Kisimoto, K. (1996). Insights into the volcanic arc mantle wedge from magnesian lavas from the Kamchatka arc. J. Geophys. Res. 101, 697-712. doi: 10.1029/95JB02404

Hoernle, K., Hauff, F., and van den Bogaard, P. (2004). 70 m.y. history (139$79 \mathrm{Ma})$ for the Caribbean large igneous province. Geology 32, 697-700. doi: 10.1130/G20574.1

Hoernle, K., Van Den Bogaard, P., Werner, R., Lissinna, B., Hauff, F., Alvarado, G., et al. (2002). Missing history (16-71 Ma) of the Galápagos hotspot: implications for the tectonic and biological evolution of the Americas. Geology 30, 795-798. doi: 10.1130/0091-7613(2002)030<0795:MHMOTG>2.0.CO;2

Holbrook, W. S., Lizzaralde, D., McGeary, S., Bangs, N., and Diebold, J. (1999). Structure and composition of the Aleutian island arc and implications for continental crustal growth. Geology 27, 31-34.

Hooper, P. R. (1997). "The Columbia River Basalt Province: current status," in Large Igneous Provinces: Continental, Oceanic and Planetary Flood Volcanism, Geophysical Monograph 100, eds J. J. Mahoney and M. F. Coffin, 1-27. doi: 10.1029/GM100p0001

Ishikawa, T., and Tera, F. (1999). Two isotopically distinct fluid components involved in the Mariana arc: evidence from $\mathrm{Nb} / \mathrm{B}$ ratios and $\mathrm{B}, \mathrm{Sr}, \mathrm{Nd}$, and $\mathrm{Pb}$ isotope systematics. Geology 27, 83-86.

Jenner, F. E., and O'Neill, H. S. C. (2012). Analysis of 60 elements in 616 ocean floor basaltic glasses. Geochemistry, Geophysics, Geosystems 13:Q02005. doi: 10.1029/2011GC004009
Kelemen, P. B., Yogodzinski, G. M., and Scholl, D. W. (2003). "Along-strike variation in the Aleutian island arc: genesis of high $\mathrm{Mg} \#$ andesite and implications for continental crust," in Inside the Subduction Factory, Vol, 138, ed J. Eiler (Geophysical Monograph, American Geophysical Union), 223-276.

Kerr, A. C., Marriner, G. F., Arndt, N. T., Tarney, J., Nivia, A., Saunders, A. D., et al. (1996a). The petrogenesis of Gorgona komatiites, picrites and basalts: new field, petrographic and geochemical constraints. Lithos 37, 245-260. doi: 10.1016/0024-4937(95)00039-9

Kerr, A. C., Tarney, J., Kempton, P. D., Spadea, P., Nivia, A., Marriner, G. F., et al. (2002). Pervasive mantle plume head heterogeneity: evidence from the late Cretaceous Caribbean-Colombian Oceanic Plateau. J. Geophys. Res. 107, ECV 2-1-ECV 2-13. doi: 10.1029/2001JB000790

Kerr, A. C., Tarney, J., Marriner, G. F., Klaver, G. T., Saunders, A. D., and Thirlwall, M. F. (1996b). The geochemistry and petrogenesis of the Late-Cretaceous picrites and basalts of Curacao, Netherlands Antilles: a remnant of an oceanic plateau. Contrib. Mineral. Petrol. 124, 29-43. doi: 10.1007/s004100050171

Knittel, U., and Oles, D. (1995). "Basaltic volcanism associated with extensional 19 tectonics in the Taiwan-Luzon island arc: evidence for non-depleted sources and subduction zone enrichment," in Volcanism Associated With Extension at Consuming Plate Margins, ed J. L. Smellie (Geological Society of London Special Publication), 77-93.

Kushiro, I. (1987). A Petrological Model of the Mantle Wedge and Lower Crust in the Japanese Island Arcs. Geochemical Society, University Park.

Le Bas, M. J., Le Maitre, R. W., Streckeisen, A., and Zanettin, B. (1986). A chemical classification of volcanic rocks based on the total alkali-Silica diagram. J. Petrol. 27, 745-750, doi: 10.1093/petrology/27.3.745

Leat, P. T., Riley, T. R., Wareham, C. D., Millar, I. L., Kelley, S. P., and Storey, B. C. (2002), Tectonic setting of primitive magmas in volcanic arcs: an example from the Antarctic Peninsula. J. Geol. Soc. Lond.159, 31-44. doi: 10.1144/0016-764900-132

Leat., P. T., Smellie, J. L., Millar, I. L., and Larter, R. D. (2003). Magmatism in the South Sandwich arc. Geol. Soc. Lond. Spec. Publ. 219, 285-313. doi: 10.1144/GSL.SP.2003.219.01.14

Lissinna, B. A. (2005). Profile though the Central American Landbridge in Western Panama: $115 \mathrm{Ma}$ Interplay Between the Galápagos Hotspot and the Central American Subduction Zone. Ph.D. thesis, Christian-Albrechts University, Kiel, Germany, $102 \mathrm{p}$.

Luhr, J. F. (1997). Extensional tectonics and the diverse primitive volcanic rocks in the western Mexican Volcanic Belt. Can. Mineral. 35, 473-500.

Luhr, J. F., and Carmichael, I. S. E. (1981). The Colima Volcanic Complex, Mexico. II. Late-Quaternary cinder cones. Contrib. Mineral. Petrol. 76, 127-147. doi: 10.1007/BF00371954

Macdonald, R., Hawkesworth, C. J., and Heath, E. (2000). The Lesser Antilles volcanic chain: a study in arc magmatism. Earth Sci. Revi. 49, 1-76. doi: 10.1016/S0012-8252(99)00069-0

Mattioli, M., Guerrera, F., Tramontana, M., Raffaelli, G., and D’Atri, M. (2000). High-Mg Tertiary basalts in southern Sardinia (Italy). Earth Planet. Sci. Lett. 179, 1-7. doi: 10.1016/S0012- 821X(00)00103-5

McCulloch, M. T., and Gamble, J. A. (1991). Geochemical and geodynamical constraints on subduction zone magmatism. Earth Planet. Sci. Lett. 102, 358-374, doi: 10.1016/0012-821X(91)90029-H

Melekhova, E., Blundy, J., Robertson, R., and Humphreys, M. C. S. (2015). Experimental evidence for polybaric differentiation of primitive arc basalt beneath St. Vincent, Lesser Antilles. J. Petrol. 56, 161-192. doi: 10.1093/petrology/egu074

Miller, D. J., and Christensen, N. I. (1994). Seismic signature and geochemistry of an island arc: a multidisciplinary study of the Kohistan accreted terrane, northern Pakistan. J. Geophys. Res. 99, 11623-11642. doi: 10.1029/94JB00059

Montes, C., Cardona, A., McFadden, R., Moron, S. E., Silva, C. A., RestrepoMoreno, S., et al. (2012). Evidence for middle Eocene and younger emergence in Central America: implications for Isthmus closure. Geol. Soc. Ame. Bull. 124, 780-799. doi: 10.1130/B30528.1

Parsons, T., Thompson, G. A., and Sleep, N. H. (1994). Mantle plume influence on the Neogene uplift and extension of the U.S. western Cordillera? Geology 22, 83-86.

Pearce, J. A., Baker, P. E., Harvey, P. K., and Luff, I. W. (1995). Geochemical evidence for subduction fluxes, mantle melting and fractional crystallization beneath the South Sandwich Island Arc. J. Petrol. 36, 1073-1109. doi: 10.1093/petrology/36.4.1073 
Pearce, J. A., Harris, N. B. W., and Tindle, A. G. (1984). Trace element discrimination diagrams for the tectonic discrimination of granitic rocks. $J$. Petrol. 25, 956-983. doi: 10.1093/petrology/25.4.956

Pearce, J. A., and Peate, D. W. (1995). Tectonic implications of the composition of volcanic arc magmas. Annu. Rev. Earth Planet. Sci. 23, 251-285. doi: 10.1146/annurev.ea.23.050195.001343

Pearce, J. A., Stern, R. J., Bloomer, S. H., and Fryer, P. (2005). Geochemical mapping of the Mariana arc-basin system: implications for the nature and distribution of subduction components. Geochem. Geophys. Geosyst. 6, 67. doi: 10.1029/2004GC000895

Peate, D. W., Pearce, J. A., Hawkesworth, C. J., Colley, H., Edwards, C. M. H., and Hirso, K. (1997). Geochemical variations in Vanuatu arc lavas: the role of subducted material and a variable mantle wedge composition. J. Petrol. 38, 1331-1358. doi: 10.1093/petroj/38.10.1331

Pichavant, M., and Macdonald, R. (2003). "Mantle genesis and crustal evolution of primitive calc-alkaline basaltic liquids from the Lesser Antilles arc," in IntraOceanic Subduction Systems: Tectonic and Magmatic Processes, eds R. D. Larter and R. T. Leat (London: Geological Society), Special Publications 219, 239-254.

Plank, T., and Langmuir, C. H. (1993). Tracing trace elements from sediment input to volcanic output at subduction zones. Nature 362, 739-743. doi: $10.1038 / 362739 a 0$

Portnyagin, M., Bindeman, I., Hoernle, K., and Hauff, F. (2007). "Geochemistry of primitive lavas of the Central Kamchatka Depression: magma generation at the edge of the Pacific Plate," in Volcanism and Subduction: The Kamchatka Region, eds J. Eichelberger, E. Gordeev, M. Kasahara, P. Izbekov, and J. Lees, 199-239. doi: 10.1029/172GM16

Putirka, K. D. (2008). "Thermometers and barometers for volcanic systems," in Reviews in Mineralogy and Geochemistry, Vol. 69, eds K. D. Putirka and F. Tepley, 61-120.

Rogers, G. C. (1985). Variation in Cascade volcanism with margin orientation. Geology 13, 495-498.

Rudnick, R. L. (1995). Making continental crust. Nature 378, 571-578. doi: $10.1038 / 378571 \mathrm{a} 0$

Sato, H. (1977). Nickel content of basaltic magma: identification of primary magmas and measure of the degree of olivine fractionation. Lithos 10, 113-120. doi: 10.1016/0024-4937(77)90037-8

Schmidt, M. W., and Jagoutz, O. (2017). The global systematics of primitive arc melts. Geochem. Geophys. Geosyst. 18, 2817-2854. doi: 10.1002/2016GC006699

Schuth, S., Rohrbach, A., Münker, C., Ballhaus, C., Garbe-Schönberg, D., and Qopoto, C. (2004). Geochemical constraints on the petrogenesis of arc picrites and basalts, New Georgia Group, Solomon Islands. Contrib. Mineral. Petrol. 148, 288-304. doi: 10.1007/s00410-004-0604-0

Serrano, L., Ferrari, L., López-Martínez, M., Maria, P., and Jaramillo, C. (2011). An integrative geologic, geochronologic and geochemical study of Gorgona Island, Colombia: implications for the formation of the Caribbean Large Igneous Province. Earth Planet. Sci. Lett. 309, 324-336. doi: 10.1016/j.epsl.2011.07.011

Sinton, C. W., Duncan, R. A., Storey, M., Lewis, J., and Estrada, J. J. (1998). An oceanic flood province within the Caribbean plate. Earth Planet. Sci. Lett. 155, 221-235. doi: 10.1016/S0012-821X(97)00214-8

Sisson, T. W., and Grove, T. L. (1993). Experimental investigations of the role of $\mathrm{H}_{2} \mathrm{O}$ in calc-alkaline differentiation and subduction zone magmatism. Contrib. Mineral. Petrol. 113, 143-166. doi: 10.1007/BF00283225

Smith, I. E. M. (2013). High - Magnesium Andesites: The Example of the Papuan Volcanic Arc. London: Geological Society, Special Publication Publications.

Smith, I. E. M., and Mitchell, P. A. (1989). High-magnesium lavas in the late Cenozoic volcanic arc associations of southeastern Papua New Guinea. Neues Jahrb. Mineral. Monatsh. H.11, 481-497.

Smith, I. E. M., Worthington, T. J., Price, R. C., and Gamble, J. A. (1997). Primitive magmas in arc-type volcanic associations: examples from the SW Pacific. Can. Mineral. 35, 257-273.

Stern, R. J. (2010). The Anatomy and Ontogeny of Modern Intra-Oceanic Arc Systems Stern. London: Geological Society, Special Publication.

Sun, S.-S., and McDonough, W. F. (1989). Chemical and Isotopic Systematics of Oceanic Basalts: Implications for Mantle Composition and Processes. London: Geological Society, Special Publication.

Suyehiro, K., Takahashi, N., Ariie, Y., Yokoi, Y., Hino, R., Shinohara, M., et al. (1996). Continental crust, crustal underplating, and low-Q upper mantle beneath an ocean island arc. Science 272, 390-392. doi: $10.1126 /$ science. 272.5260 .390

Tamura, Y. (2003). "Some geochemical constraints on hot fingers in the mantle wedge: evidence from NE Japan," in Intra-Oceanic Subduction Systems: Tectonic and Magmatic Processes eds R. D. Larter and P. T. Leat (London: Geological Society, Special Publications), 221-237. doi: 10.1144/GSL.SP.2003.219.01.11

Tamura, Y., Ishizuka, O., Stern, R. J., Nichols, A. R. L., Kawabata, H., Hirahara, Y., et al. (2013). Mission immiscible: distinct subduction components generate two primary magmas at Pagan volcano, Mariana arc. J. Petrol. 55, 63-101. doi: 10.1093/petrology/egt061

Tamura, Y., Ishizuka, O., Stern, R. J., Shukuno, H., Kawabata, H., Embley, R W., et al. (2011). Two primary basalt magma types from Northwest Rota-1 volcano, Mariana arc and its mantle diapir or mantle wedge plume. J. Petrolo.52, 1143-1183. doi: 10.1093/petrology/egr022

Tamura, Y., and Tatsumi, Y. (2002). Remelting of an andesitic crust as a possible origin for rhyolitic magma in oceanic arcs: an example from the Izu-Bonin arc. J. Petrol. 43, 1029-1047. doi: 10.1093/petrology/43.6.1029

Tatsumi, Y. (1982). Origin of high-magnesian andesites in the Setouchi volcanic belt, southwest Japan II. Melting phase relations at high pressures. Earth Planet. Sci. Lett. 60, 305-317. doi: 10.1016/0012-821X(82)90009-7

Tatsumi, Y., and Eggins, S. (1995). Subduction Zone Magmatism. Boston, MA: Blackwell Science.

Tatsumi, Y., Furukawa, Y., and Yamashita, S. (1994). Thermal and geochemical evolution of the mantle wedge in the northeast Japan arc 1. Contribution from experimental petrology. J. Geophys. Res. 99, 22275-22283. doi: 10.1029/94JB00283

Tatsumi, Y., and Maruyama, S. (1989). "Boninites and high-Mg andesites: tectonics and petrogenesis," in Boninites and Related Rocks, ed A. J. Crawford (London: Unwin Hyman) 50-71.

Tatsumi, Y., Sakuyama, M., Fukuyama, H., and Kushiro, I. (1983). Generation of arc basalt magmas and thermal structure of the mantle wedge in subduction zones. J. Geophys. Res. 88, 5815-5825. doi: 10.1029/JB088iB07p05815

Wegner, W., Wörner, G., Harmon, R. S., and Jicha, B. R. (2011). Magmatic history and evolution of the Central American land bridge in Panama since Cretaceous times. Geol. Soc. Ame. Bull. 123, 703-724, doi: 10.1130/B30109.1

Whattam, S. A., and Stern, R. J. (2015). Late Cretaceous plume-induced subduction initiation along the southern margin of the Caribbean and NW South America: the first documented example with implications for the onset of plate tectonics. Gondwana Res. 27, 38-63. doi: 10.1016/j.gr.2014.07.011

Whattam, S. A., and Stern, R. J. (2016). Arc magmatic evolution and the construction of continental crust at the Central American Volcanic Arc system. Int. Geol. Rev. 58, 653-686. doi: 10.1080/00206814.2015.1103668

White, W. M., and Patchett, J. (1984). Hf-Nd-Sr isotopes and incompatible element abundances in island arcs: implications for magma origins and crust-mantle evolution. Earth Planet. Sci. Lett. 67, 167-185. doi: 10.1016/0012-821X(84)90112-2

Winchester, J. A., and Floyd, P. A. (1977). Geochemical discrimination of different magma series and their differentiation product using immobile elements. Chem. Geol. 20, 325-343. doi: 10.1016/0009-2541(77)90057-2

Wörner, G., Harmon, R. S., and Wegner, W. (2009). Backbone of the Americas: Shallow Subduction, Plateau Uplift, and Ridge and Terrane collision, Vol. 204, eds S. M. Kay, V. A. Ramos, and W. R. Dickinson (Geological Society of America Memoir), 183-196. doi: 10.1130/2009.1204

Xia, X., Song, S., and Niu, Y. (2012). Tholeiite-boninite terrane in the north Qilian suture zone: implications for subduction initiation and back-arc basin development. Chem. Geol. 328, 259-277. doi: 10.1016/j.chemgeo.2011.12.001

Conflict of Interest Statement: The author declares that the research was conducted in the absence of any commercial or financial relationships that could be construed as a potential conflict of interest.

Copyright (c) 2018 Whattam. This is an open-access article distributed under the terms of the Creative Commons Attribution License (CC BY). The use, distribution or reproduction in other forums is permitted, provided the original author(s) and the copyright owner(s) are credited and that the original publication in this journal is cited, in accordance with accepted academic practice. No use, distribution or reproduction is permitted which does not comply with these terms. 